\title{
Contracting for technology transfer: patent licensing and know-how in Brazil
}

\author{
Catalina Martinez* and Pluvia Zuniga** \\ * CSIC-IPP, Institute of Public Goods and Policies, Consejo Superior de Investigaciones \\ Científicas, Madrid, Spain \\ catalina.martinez@csic.es \\ ** UNU-MERIT, United Nations University and Maastricht Economic and Social Research \\ Institute on Innovation and Technology, Maastricht, the Netherlands \\ and Organisation for Economic Cooperation and Development (OECD) \\ mzuniga@unu.merit.edu
}

Accepted for publication in Taylor\&Francis journal Industry and Innovation

Please quote the published version: http://dx.doi.org/10.1080/13662716.2016.1263889

\begin{abstract}
Using contract level data, we study the relation between the inclusion of know-how in cross-border patent licensing agreements and the contractual terms used by firms to deal with moral hazard risks. We use official data on international technology contracts with patent licensing terms registered by affiliated and unaffiliated parties before the Department of Technology Transfer of the National Institute of Intellectual Property (INPI) in Brazil between 1996 and 2012. We find that contracts between unaffiliated parties involving know-how transfer show distinctive contractual and technology features compared to the rest: (i) they involve younger but lower quality technologies (compared to contracts without know-how); (ii) they are more prone to up front lumpsum payments than royalty or combined payments (royalty and fixed); and (iii) they are more likely to be accompanied by the licensing of other IPRs, in addition to patents, such as trademarks.
\end{abstract}

Keywords: patent licensing, know-how, trademarks, technology contracts, Brazil

JEL: OD32, D23, L24 


\section{Introduction}

Research has shown that patents encourage the development of technology markets and facilitate the division of innovative labor across firms and sectors (Arora $e t$ al, 2001; Arora and Gambardella 2010). By reducing informational asymmetries and lowering the cost of transactions, patents allow partners to contract for legally protected pieces of knowledge and contribute to making technology markets more fluent. However, technology transfer often requires more than just the permission to use technology covered by patents; and not all necessary knowledge may be protected by intellectual property rights (IPRs). In many cases, the transfer of know-how, which is often tacit knowledge owned by the technology firm, is critical to the successful exploitation of the transferred technology. Tacit means that knowledge is embedded in persons (idiosyncratic to its creators), and as such it is neither easily codifiable (in blueprints, designs and patents) nor transferable without incurring into important contractual hazards (Polanyi 1966; Rosenberg 1983; Pavitt 1987). Because it is nonprotectable through IPRs, or protected only through informal modes of protection, namely trade secrecy, tacit knowledge is hard to articulate and transfer to other firms through arm's length contracting (Teece 1986).

The objective of this study is to investigate under what contractual conditions and technology contexts contracts involving the licensing of patents also include explicit clauses for the transfer of know-how (i.e. the unprotected component of the transferred technology). While a rich theoretical literature exists on the optimal design of licensing contracts (e.g. Macho-Stadler et al, 1996; Jensen and Thursby 2001; Choi 2001), the empirical analysis of how moral-hazard and technology attributes such as age of technologies or patent scope reflect in contract design remains scarce. Furthermore, in spite of a consensus among scholars about the importance of know-how in technology transfer (Taylor and Silberston, 1973; Arora and Gambardella, 2011) and innovation, and the notorious growth of global technology transactions (Zuniga and Guellec, 2009), despite technology markets imperfections (Kani and Motohashi (2011), the empirical examination of how companies deal with the exchange of know-how is yet to be established. The dearth of contract-level data evidently remains an important limitation in pursuing this venue of research. 
Taking advantage of contract-level data registered by the Department of Technology Transfer of the National Institute of Intellectual Property (INPI) in Brazil, we study the factors that explain the incidence of know-how transfer-defined as the provision of scientific and technical assistance services and supply of technology (other than those protected through patents by the licensor firm in Brazil) in patent licensing contracts between international companies (licensors) and domestic firms (licensees).

We study differences between contracts reporting transfers of know-how ("technology packages") and contracts that are restrained to patent licensing ("standalone" patent licensing). Using information from contract-level data, we are able to test several hypothesis advanced by the theoretical literature that are expected to influence know-how transfer and help deal with asymmetric information and uncertainties surrounding technology transfer. More precisely, we explore the association between the provision of know-how transfer and (i) the age and quality of the technology; (ii) the payment choice - with upfront payment schemes being a way to deal with moral hazard and misappropriation risk; (iii) the existence of previous relationships between contracting parties; (iv) the provision of other IPRs (e.g. trademarks, designs and industrial models) in addition to patents; and (iv) the strength of the licensed patents, as reflected in patent features such as patent scope and international family links. Our aim is to provide new empirical insights into the economic fundamentals shaping patent licensing contracts and the ways firms deal with the moral hazard surrounding the transfer of know-how.

We are particularly interested in investigating whether providing know-how relates to the provision of other intellectual assets supporting technology transfer and/or innovation exploitation as reflected in the accompanying licensing of other IPRs. Apart from reflecting potential complementarity effects (e.g. Arora, 1995; 1996), a positive association between know-how and provision of other IPRs -such as trademarks- may indicate a stronger partnership between parties. In principle, the licensing of a brand would require licensees supplying their counterparts with additional intellectual competences provided by IPRs other than patents- necessary to bring products to the markets. An IPR package also means the use of a multi-protection strategy for an invention or technology.

We explore these questions for the case of Brazil. Brazil is interesting not only for its potential as target market for technologies, being the fifth largest country in the 
world and the sixth economy in terms of GDP (IMF 2011), but also for its strong science base and growing technological capabilities. The country takes the fifteenth position in the world ranking in terms of scientific production (Scimago, 2012). Patent requests to the National Institute of Industrial Property (INPI) increased 23 percent in the period from 1999-2004 to 2005-2010 (Dutz et al., 2012). Over the last decade, the government has increased support to science, technology development and innovation substantially through different policy measures including direct and indirect incentives for innovation investment and technology transfer. The Program BNDES Innovation (Ferrero Zucoloto et al., 2013), for instance, provides financial support to business innovation investment. It finances, inter-alia, $R \& D$ investments, the acquisition of new machinery and equipment (produced in Brazil and imports without a similar national version), activities related to the transfer and absorption of technology (technology services) and training.

We rely on data at the contract level for all patent licensing contracts registered at INPI during the period 1996-2012. We use additional information from several sources (company's websites and news reports available online) to distinguish licensing contracts by foreign firms to unaffiliated firms (in Brazil) from licensing taking place within multinational company groups (licensing to Brazilian affiliated companies). After cleaning, parsing and coding the data, we complemented contract data with patent level data from PATSTAT October 2012, which allowed us to dig further into invention and patent-level features potentially affecting the provision of know-how.

Using this information, our study seeks to shed new light in the analysis of technology contracting and enrich previous research in different dimensions. First, we provide new insights on the understanding of patent licensing: how contracts are designed and how firms deal with the transfer of know-how based on official data from licensing contracts. The availability of key information on contract features and their match with patent data, allow us to confront some of the main arguments of economic theory with contract-level data. Our paper brings therefore a dimension of analysis seldom used in the literature.

In the study of technology transfer transactions, researchers are faced with the problem of lack of data, as contract information is kept secret among parties. This has led most economic studies to rely on survey data for particular set of transactions or surveys on inventors based on individual patent-level information -neglecting the fact 
that licensing of IPRs often come in technology and IPR packages (e.g. government survey on international technology agreements as in Arora (1996); licensing Survey by the Licensing Executive Society members from France (Bessy et al 2010); the PATVAL Survey (I-II) (Gambardella et al. 2007); the RIETI-Georgia Tech Inventor Survey (Nagaoka and Walsh, 2009)). Other studies have used proprietary databases based on publicly available information such as SEC filings, corporate information from news clips or annual reports (e.g. Anand and Khanna 2000; Hegde 2014). Most of these studies, however, are either restrained to few industries or data are based on voluntarily disclosed information resulting in selection bias issues. Although our data has other limitations, we are able to deal with some of the drawbacks just mentioned and test several hypotheses advanced by the literature regarding the strategic design of contract and their relationship with technology and patent features. In addition, our work can be seen as a first effort in the empirical analysis of patent licensing contracts in the context of an emerging country.

Our second contribution is precisely to provide new insights on international patent licensing activity from developed to developing countries. The acquisition of know-how is of crucial importance for firms in the process of catching-up (Alvarez et al, 2002; Johnson, 2002; Fagerberg et al, 2010). For middle-income countries, evidence indicates that foreign technology licensing can have important benefits on firms by means of learning, know-how acquisition, and complementarities with internal R\&D capacity (Lee, 1996; Arora, 1996; Griffith et al, 2004). Chung and Lee (2015) show that foreign technology licensing can be a key element to the firm learning process in catching up economies as it mostly occurs before firms engage in in-house R\&D. Firms engaged in both activities over time show a higher patent propensity and product introduction rates. It is important then to better understand in what conditions and through which arrangements know-how transfer occurs and accompanies codified technology acquisition.

The paper is organized as follows. In section 2 we review the literature on the factors influencing contracting of technology and the licensing of know-how. We discuss the rationale underlying the decision to license technology packages combining patent licensing with protected (other IPRs) and non-protected knowledge (know-how). Section 3 sets out our hypotheses and section 4 describes the data and the methodology 
used. Section 5 presents and discusses our results. The last section concludes and discusses future venues of research.

\section{Literature Review: Know-how and Technology Contracting}

Know-how is a private knowledge asset developed by innovative firms. It is often tacit, embedded in people, and results from accumulated experiences, learning-by-doing, and specific context conditions (Polanyi 1966; Rosenberg 1983; Pavitt 1987). In practical terms, know-how transfer can take the form of training, R\&D services, demonstrations, industrial secrets or any other type of knowledge or technical services that is provided by the experts who developed the technology. Thus, know-how transfer entails sharing important information about procedures and practices, rules of thumb, and guidance for modifications to suit different circumstances (Teece, 1986; Arora, 1996). Know-how is hard to codify in blueprints or manuals, it is therefore unprotected (by formal legal means) and requires consequently face-to-face interaction to be transferred. Generally speaking, know-how tends to be the "non-verifiable" part of the technology.

The literature recurrently stresses the difficulties in the transfer of tacit knowledge through markets. Macho-Stadler et al. (1996) explain that information failures are particularly exacerbated in the case of know-how transfer because it is often non-protectable technical knowledge -know-how is not an invention, in the sense of intellectual property right laws. According to Taylor and Silberston (1973) know-how is one of the most strongly contested points in technology transfer agreements, because transferring know-how usually involves benefits and obligations that are difficult to foresee. More generally, the tacitness of knowledge increases contractual hazards (Macho-Stadler et al, 1996; Arora, 1995; Mendi, 2007). Given this scenario, know-how transfers are more likely to occur exclusively between affiliated firms (Caves et al. 1983; Kogut and Zander, 1993; Mendi, 2007). This situation prevails the more costly transactions are (e.g. with breakthrough technology requiring new types of equipment), and the more complex and tacit is the knowledge required to succeed technology transfer (Williamson, 1991; Kim, 1997).

According to theory (Arrow, 1962), contractual hazards from both sides (Caves et al. 1983; Contractor 1981; Teece 1986) could discourage firms from sharing knowhow outside the corporation. From the licensor's perspective, disclosed information can be misappropriated. Once know-how is transferred the licensee may have no further 
incentive to comply with the agreed terms -he may try not to pay after learning the know-how, he may not tell the truth about the output (if payments are output-based), or he may use and even sell the knowledge to others. From the licensee's perspective, the seller of the technology (licensor) may not fully disclose information or not fully ensure the transfer of know-how required for the exploitation of technology to succeed after the contract has been signed. As a result, actions cannot be completely contracted upon, monitoring would involve additional agency costs, and the full specification of assets to be transferred may be impossible.

The literature has provided a number of explanations and potential factors influencing know-know transfer to unaffiliated companies and the context conditions in which they take place. A group of studies relevant to our work have looked at the role of complementary knowledge, bundling and timing in the transfer of technology (Arora 1995 and 1996; Mendi 2007). A second strand of research has analyzed the provision of know-how from the perspective of payment schemes (Macho-Stadler et al. 1996; Jensen and Thursby 2001; Choi 2001; Bessy et al. 2010; Cebrian 2009; Hegde 2014). We reviewed these studies and classed their lessons into five types of potential factors influencing the combined provision of know-how transfer and patent licensing: $(a)$ Bundling and contract length; (b) Payment schemes; (c) Technology and patent attributes; $(d)$ Firms' features and prior relationship; and $(e)$ Industry effects. In what follows we try to put these findings in context and relate them to our analysis of patent licensing contracts providing both codified technology (patents) and tacit knowledge (know-how).

\section{(a) Bundling and Contract Length}

The idea of "bundling" in the context of know-how in technology contracts was early discussed by Teece (1986), Contractor (1981) and Arora (1995) who explained that "tied sales" improve the efficiency of the contracts involving know-how transfer. Arora (1995) showed that one way to solve the opportunistic behavior of the licensee is to explicitly include both patent licensing and know-how transfer in the terms of the contract. The rationale is that protection of intellectual assets would facilitate the design of contracts and the provision of "complementary" knowledge or technological inputs. Complementarity means that the joint provision of different supportive inputs would make exploitation of the technology transferred more efficient rather than provisioning 
separately each of the parts. Arora (1996) tested this idea in a study of 144 international technology contracts involving Indian firms, where he found that that the provision of complementary technology transfer (e.g. patent rights, plant commissioning and equipment acquisition) was related to know-how transfer (provision of training, quality control or support by licensor in the creation of $R \& D$ units).

Bundling also relates to the licensing of intellectual property rights in addition to patents -such as industrial designs, copyrights or trademarks- necessary to the realization and commercialization of innovation. IPR bundles then help maximize returns to commercialization while reinforcing contract compliance. In many cases, a technological innovation entails a package of intellectual pieces required to instrument and develop an invention or necessary to succeed its commercialization.

Further, when the technology is transferred with an IPR bundle, the commercialization efforts of the licensee are more closely tied to the reputation of the licensor and vice versa. In particular, an IPR bundle having trademarks and know-how licensing implies a strong commitment by the licensor to provide not only technology but also market reputation and complementary knowledge to fully exploit and commercialize the licensed technology. ${ }^{1}$

As stressed in the literature, the main economic function of trademarks is not, as with patents, to provide firms with $R \& D$ incentives, but to signal quality and good will, promoting efficiency by reducing consumer search costs (Landes and Posner, 1987; Bessen and Raskind, 1991, Economides, 1998). In this context, the explicit addition of know-how transfer to the technology package may be interpreted as a way to guarantee the quality of the product sold by the licensee with the brand name of the licensor and produced with his patented technology, and thus, more likely to be related to product than process innovations.

The transfer of know-how has also been related to contract length. The duration of contracts could be used by licensors as a way to mitigate opportunistic behavior and moral hazard in the licensing of know-how. Mendi (2007) examined 165 technology contracts signed in 1991 by Spanish firms and tested the relation between contract duration and know-how provision. Accordingly, because patents uncover codified

\footnotetext{
${ }^{1}$ Trademark licensing indicates the use of a company (or product) brand together with the licensing of a product innovation. This means that the licensor gives the rights to use and commercialize his products to other parties (or services) under his insignia.
} 
technology and are protected legally, contract duration may be expected to be less relevant in the context of technology transactions based on patents as opposed to transactions involving know-how. He found that shorter scheduled contracts were less likely to include the transfer of know-how while no significant relation was found in contracts involving only patents.

\section{(b) Payment Schemes}

The type and structure of payments in technology contracts are revelatory of moral hazard problems and asymmetric information between licensor and licensee, as suggested by Jensen and Thursby (2001) model. The choice of payment depends on several aspects such as the level of maturity of technology (Rockett, 1990), (e.g. Choi, 2001); competition in the downstream market (e.g. Katz and Shapiro, 1985) double-side moral hazard problem and the degree of involvement of the licensee in the development of the licensed technology (e.g. Choi, 2001) as well as the degree of codification (Bessy et al. (2010), among other factors.

Traditionally, payment schemes can be of two types - variables (royalty rates) and/or fixed payment (lump-sum schemes) - or a combination of these (two-tariff payment). For the case of know-how, the literature provides arguments for and against the use of royalties. Starting from Contractor (1981), it has been argued that outputbased royalties would not be the best strategy to compensate the licensor for technical assistance or know-how provision. Because termination of contracts is of no concern for licensees, once the tacit knowledge is provided and lacking a deterrent effect, licensing contracts would take the form of a one-off lump-sum upfront payment to ensure economic returns from the transaction rather than a royalty-rate (Williamson, 1991). A different view is offered by Macho-Stadler et al. (1996). They showed empirically that licensing agreements with know-how transfer will typically include royalty payments but their analysis relates this result only to moral hazard issues on the side of the licensor. According to authors, “[r] oyalties raise the licensor's incentives to transfer the best current know-how" which is crucial for the recipient firms to fully assimilate the licensed technology.

Recent studies on payment structures emphasize that tacitness of knowledge increases moral hazard from the licensee's side pushing licensors to adopt fixed types of payments (or a combination) in order to ensure economic returns. This relation however 
seems to be moderated by the use of proprietary technology -when contracts bundle patents with know-how- which increases certainty and reduces the licensee's margin for contract defection. In Bessy et al. (2010), the more tacit the transferred resources are (e.g. such as technical assistance and know-how), the more contracts rely on upfront payments (as opposed to royalties). Using a dataset of 553 technology contracts in France, they find that royalty rates (ex-post payment) are more often used when technology is codified (patent-based) whereas in contracts involving more tacit knowledge, measured by an index summarizing a set of know-how and consultancy services, the prevailing mode of payment is upfront lump-sum payment (ex-ante). Cebrian (2009) finds a similar result excepting for the case of bundling know-how with patents. She examined 925 licensing agreements in Spain, signed between 1942 and 1972. She finds that know-how transfer (technical services provided by foreign personnel and training) is more likely related to fixed payments although bundling know-how with patents is negatively related to the likelihood of choosing lump sum payment (compared to the use of only-royalties) since the probability of the moral hazard of the licensee side occurring is lower.

Finally, Hegde (2014) studies 505 license agreements of biomedical inventions in the United States and finds that the importance of the licensors' tacit knowledge is associated with higher royalty rates, but when such knowledge can be codified (e.g. through patents or blueprints) licensees prefer upfront fees or milestone payments. He also finds that when the licensor can stipulate measurable benchmarks to ensure that the licensee exerts the necessary effort to commercialize the invention, non-contractible licensee effort is associated with minimum annual payments, but in the absence of such safeguards it is associated with upfront payments. ${ }^{2}$ In this case, we are talking about early stage innovations which require development or market investment by licensee in order to succeed commercialization.

\section{(c) Technology Features}

Another key feature of technology influencing the transfer of know-how is age or degree of maturity of the technology. In principle, the older the technology, the lower the uncertainty about its quality, and the lower the risk associated with the provision of

\footnotetext{
${ }^{2}$ His sample includes licensing contracts involving high value transactions - the mean upfront payment to inventors is $\$ 1.5$ million, as these were reported as material transactions by public corporations in their U.S. Securities and Exchange Commission (SEC) filings.
} 
tacit knowledge (see further details in Gallini and Wright (1990) and Rockett (1990)). Mansfield and Romeo (1980), in a study of international technology transactions by United States-based companies find that technology licensed to unaffiliated firms is generally older than in the case of affiliated firms. ${ }^{3}$ However, other studies suggest that the provision of technical services would decrease in importance with the age of technology. Kim (1997) found evidence of this relation in an analysis of technical services in a sample of 39 pharmaceutical licenses from Korea. He found the probability of providing technical services to be decreasing in the years of patent protection remaining and increasing in the complexity of technology.

According to the technology transfer model of Macho-Stadler et al (1996), the licensor will be interested in transferring know-how when: (i) the cost of know-how transfer is low; (ii) the demand of the licensee's product is high; (iii) the know-how is valuable, and (iv) the technology is important, if the know-how and the technology are complements. While we are not in the position to measure (i)-(iii), we can test for the possibility of (iv) which is the most relevant to our concerns. Thus, if know-how and technology are complements, the likelihood of providing know-how will increase with the value of technology.

\section{(d) Patent Attributes}

Arora (1991) explains that the extent to which patents can be used to protect know-how depends upon the degree to which the know-how being provided is related to the technology covered by the patent, and upon the strength of patent protection. Previous studies have shown that strong protection of patents (or strong patents) is fundamental for firms engaging in licensing transactions (Arora and Gambardella, 1994; Gambardella et al, 2007). In the study of technology contracts in India (Arora 1995), the probability of providing technical services was higher when the contract included a patent license or a turnkey construction contract. A better enforcement of patented technology increases the effectiveness of the contract for know-how as well (Arora 1995 and 1996). In their study of 1365 licensing deals involving US partners Anand and

\footnotetext{
${ }^{3}$ In her study of technology contracts in Spain, Cebrian (2009) also argued that adverse selection is not really an issue in explaining payment schemes. Accordingly, these problems are expected to be less important in developed-developing countries technology transfer agreements, given that the technologies transferred have already been proven in the licensor's country.

${ }^{4}$ On the contrary, when technology and know-how are substitutes, i.e. they are somehow "interchangeable", a better technology implies a low-valued know-how.
} 
Khanna (2000) found significant variation across industries in their propensity to engage in contractual features such as exclusivity and technology transfer and related these variations to the strength of IPRs across sectors, among other factors.

In our case, we cannot discern between technology contracts with patents and without patents because all our contracts involve the licensing of patents. But what we can do is to examine whether certain features of patents related to patent strength correlate with the inclusion of know-how provision. According to the literature, a greater effectiveness of patents helps reduce uncertainty and asymmetric information surrounding technology market transactions (Arora and Ceccagnoli, 2006) and induces therefore more licensing of technology. This has been measured with surveys asking firms how much revenues were due to protection. ${ }^{5}$ Recently, De Rassenfosse et al., (2016), find evidence of the role of patents in helping with appropriation of innovation (confirming the protection role) in the conclusion of technology transactions. ${ }^{6} \mathrm{We}$ do not have information about the effectiveness of patents in firms' revenues or any other measure of appropriation effect, but we can look at the patent breadth or scope of patents licensed.

Another way of considering "strong patents" is in their breadth -which is in part influenced by the patentee (Merges and Nelson, 1990, Klemperer 1990) who seeks to maximize profitability from protection by protecting inventions through numerous claims and expanding patent protection to a wide array of technology classes. Lerner (1994) reports evidence of the economic importance of patent breadth for firms as measured by the number of IPC classes covered in patents owned by biotechnology firms and the market value of these companies.

\section{(e) Firm features and Prior Relationships}

Research has shown that prior relations are a key factor influencing the design of contracts. Firms rely on institutional responses such as long-term contracting to deal with moral hazard (Anand and Khanna 2000, Arora, 1996; Arora et al, 2001). These mechanisms, however, are deemed only effective in the context of repeated interactions that allow to build up reputation or to apply credible threats to punish opportunistic

\footnotetext{
${ }^{5}$ See Arora and Ceccagnoli (2006).

${ }^{6}$ No evidence was detected in regards to the role of patents as "information disclosure" instrument and their incidence on reaching a technology contract.
} 
behavior (Arora, 1996). When companies engage in repetitive contracts over time, one can expect that they are committed in a cooperative relationship.

Prior relationships, which could be seen as a proxy for trust among parties, increase the efficiency of the contracting process because risks and transactions costs associated with double-sided moral hazard decrease (e.g. Anand and Khanna, 2000; and Bessy et al. 2010). Therefore we expect contracts involving this type of partners to be more prone to know-how transfer. Jensen et al., (2015) recently showed that a high level of trust between parties (i.e. know each other from a previous business) is a key determinant in reaching a technology transaction -compared with those with low levels of trust.

In regards to partners' size, the reputation and economic strength of the licensee influence contract design choice between the types of payments. A large licensee may not be as risk-averse and may be willing to engage in more complex transactions than a small licensee, even in the presence of information asymmetries. In his study of technology contracts in India, Arora (1996) finds that larger licensee firms were more likely to engage in know-how transfers (R\&D service and quality control services).

\section{(f) Industry Effects}

The literature has also shown that important differences across industries prevail in the propensity to engage in technology (and knowledge) transactions which are reflected in the ways contracts are designed (Anand and Khanna 2000, Aulakh et al 2013). As noted by Anand and Khanna (2000:127), "the ability to appropriate the gains from innovation differs systematically across sectors, and appears closely linked to the ability to clearly articulate the know-how embodied in the underlying technologies. In chemicals, for instance, articulating such information is easy, hence contracts specifying the limits to its use can be more easily designed. In electronics and computers, however, information is highly context-dependent". We therefore expect industries that are more mature and with easier codification of knowledge -such as chemicals and related- to be more prone to know-how transfer as opposed to complex industries such as electronics and computers. The authors also explained that variations in the industry propensity to know-how transfers (and other contract features such as exclusivity) could also be related to differences in the IPR propensity across industries. 


\section{Hypotheses}

From the literature above reviewed, our first hypothesis relates to the existence of potential complementarities between know-how and other intellectual assets that help reduce asymmetric information and improve contract enforcement. When patent licensing contracts include explicitly the provision of know-how, we expect this transaction to be accompanied by the licensing of complementary IPRs (notably trademarks and industrial designs). While causality could go in both ways, we argue that the transfer of know-how can be associated to the licensing of IPR packages given that: (i) enhanced protection helps mitigate opportunistic behavior exacerbated with know-how transfer and makes the contract more coercive (Macho-Stadler et al., 1996; Cebrian, 2009) and (ii) reputational effects are higher in downstream licensing (involving product/company trademark licensing) - which motivates the licensor to ensure quality through provision of tacit knowledge.

We are particularly interested in the provision of trademark rights in patent licensing with know-how. The licensing of trademark rights indicates the use of a company (or product) brand together with the licensing of a product innovation. Having trademark licensing along with patent licensing would indicate that the licensor wants to make sure the licensee benefits from the brand reputation he has built in other countries, so that he gets full return of his investment by maximizing licensing payments.

Our second hypothesis relates to the form of payment and its association with know-how, but theory does not offer a clear cut response. When moral hazard issues are mostly on the licensee side, as it could plausibly be the case in international transfers to developing countries with weak patent protection, we would expect patent licensing contracts containing know-how to favor one-off upfront payments rather than royalties (or mixed types of payments). Although new global technology leaders are emerging from Brazil, most of domestic companies are still technology importers and intellectual property protection remains a concern for multinational companies. The risk of opportunistic behavior by the licensee would then be minimized with upfront fees, which equals the transfer to a sale of the technology.

However, the result is not so straightforward in the presence of double sided moral hazard issues. In line with Hegde (2014), when the inventor's knowledge can be codified and specified in patents and other forms of written guidelines, developers prefer upfront fees or milestone payments. However, if codification is not available, the 
necessity of the inventor's tacit knowledge for downstream commercialization and further development would be associated with higher royalty rates, as argued in initial models.

Our third hypothesis refers to the age and value of technology. We posit that contracts with know-how transfer are more likely to include younger and higher quality technologies than contracts without know-how transfer. In terms of age, a negative relationship has often been put forward in theoretical models (Gallini and Wright, 1990; Rockett, 1990) and confirmed in some empirical studies (e.g. Kim, 1997): younger technologies are often more complex than mature technologies and might require new skills and specific knowledge for their implementation. In terms of value, we would expect variables related to the value of the technology to be positively associated to the transfer of know-how, provided that the value of know-how increases with the value of the technology (Macho-Stadler et al. 1996). While, to our knowledge, there is no previous research precisely on the existence or not of know-how transfer clauses and the value of the technology transferred, some recent studies suggest that the quality of the technology (i.e. proxied by patent attributes) is positively associated to the speed of its commercialization (Wagner and Wakeman, 2016) and exploitation of patents (see Torrisi et al., 2016).

Our fourth and last hypothesis relates to the existence of prior relationships between the contracting parties. We identify those for a sub-set of licensing contracts and examine the importance of previous relationships in the provision of know-how. As discussed in the previous section, we expect prior relationships -which could be seen as a proxy for trust among parties - would increase the efficiency of the contracting process as double-sided moral hazard decrease (e.g. Anand and Khanna, 2000; and Bessy et al., 2010; and De Rassenfosse et al., 2016). Therefore, we hypothesize that contracts involving partners with prior relations are more prone to know-how transfer.

In sum, based on previous studies, we expect international patent licensing contracts with know-how transfer to Brazilian companies to be more likely to include the licensing of other IPRs, notably trademarks; to include up-front lump sum payments; to relate to younger and higher quality inventions; and to involve parties with prior relations. Nevertheless, our analysis remains exploratory as regards the occurrence of IPR bundles and different payment schemes in technology contracts with know-how transfer as their relation is not clear cut. A technology contract with know-how transfer 
that relies solely on one off upfront payments can be interpreted as an agreement where the licensor effectively sells the technology to the licensee together with the right to use it, as no further payment is required from the licensee after the technology is transferred. In contrast, a technology contract with know-how transfer that involves the licensing not only of patents but also of trademarks and industrial designs, implies that the actions of the licensor and the licensee will still have an effect on the implementation of the contract over time and the parties would thus probably prefer more complex payment schemes, including milestone payments or royalties.

Our study differs from previous works in important ways. As opposed to Arora (1996), Macho-Stadler et al., (1996) or Cebrian (2009), who analyzed technology licensing contracts (with and without patents), we analyze the provision of know-how conditional on the licensing of patents. Our universe is thus patent licensing contracts. This enables us to include detailed characteristics of the technology in the analysis by drawing from patent databases. It also allows us to evaluate specific contractual and technology features characteristics previously understudied in the literature, such as IPR bundling, where other IPR licensing agreements are included in the contract in addition to patent licensing (Helmers and Schautschick (2013).

\section{Data and Methodology}

Our data come from the Department of Technology Transfer of the National Institute of Intellectual Property (INPI) in Brazil and refer to all technology contracts involving the licensing of industrial property rights (patents, utility models and design rights) filed in Brazil that were registered at the INPI during the period 1996-2012. According to Brazilian law (art. 211 of the Industrial property law 9279/1996), the registration of licensing agreements and those involving technology transfer before the INPI is mandatory for the following purposes (out of these purposes it is not required to report any information): (i) opposability against third parties; (ii) deduction by the Brazilian party of the amounts paid to the foreign party for income tax purposes (registration with the Central Bank of Brazil is also required); (iii) remittance of payments abroad (registration with the Central Bank of Brazil is also required); and (iv) creation of a presumption of non-violation of the economic order, since the INPI is considered an auxiliary agency of the economic authorities. The latter refers to compliance with competition policy frameworks and other market regulations (e.g. for purpose of detection/prevention of anti-competitive behavior and anti-trust; e.g. collusive 
practices). ${ }^{7}$ Licenses and other contracts were for some time subject to antitrust review by INPI. ${ }^{8}$ Such responsibility ended in 1996 and ever since the INPI has been mainly endorsed with the responsibility of contract registration.

INPI classifies technology contracts into five different categories: ${ }^{9}$ i) use of trademarks (UM); ii) exploitation of patents, utility models or industrial designs (EP); iii) technology supply (including know-how) (FT); iv) franchising (FRANQUIA); v) scientific and technical assistance (SAT); vi) combinations of two or more of the previous categories. ${ }^{10}$ Our data is a subset of the full INPI database on technology contracts as it only includes contracts with EP. Our sample represents around 5 percent of all certificates of technology contracts registered at INPI, but comprises all standalone contracts for patent exploitation as well as other technology contracts where patent exploitation is combined with one or more other categories. ${ }^{11}$

According to aggregate statistics published by INPI, certificates of contracts for stand-alone patent licensing represented around $3 \%$ of all certificates registered at INPI annually between 2000 and 2012. The category 'two or more categories combined', which includes certificates of contracts with and without patents, always combined with other types of technology transfer, represent around 5\%. We are aware that we are dealing with the most uncommon form of technology transfer (8\% of technology contracts) occurring in Brazil, as patent licensing is a special form of legal contracting requiring special conditions for both licensor and licensee, and perhaps the most sophisticated form of technology transfer. As discussed earlier, multinational firms may prefer incur into foreign direct investment and licensing to affiliates to keep control of technology and prevent leak out and misappropriation of knowledge by local competitors.

\footnotetext{
${ }^{7}$ The parameters that are observed are the existence of contract conditions that restrict competition, such as export restrictions, conditions preventing challenges to validity of rights, exclusive bundling, etc. In such cases, contractors are advised to justify the reasonableness of such clauses and contracts are validated by INPI following the rule of reason.

${ }^{8}$ This role was revoked with the enactment of the 1996 Industrial Property, which eliminated the functions of the INPI to regulate the transfer of technology and bounded its action to contract registration to the extent that the effects sought are compatible with the strict legal standards (Borges Barbosa, May 2012). For anti-trust contentious cases, contracting parties should address to the Department of Justice.

${ }^{9} \mathrm{http} / / /$ www.inpi.gov.br/portal/artigo/guia_basico_contratos_de_tecnologia.

${ }^{10}$ Fornecimento de Tecnologia (FT): Contract that stipulates the conditions for the acquisition of knowledge and techniques not protected by legal rights, including knowledge and technologies not protected by industrial property rights applied or granted in Brazil (know-how). Serviços de Assistência Técnica e Científica (SAT): Services that include the acquisition of techniques to elaborate projects or studies and the provision of specialized services.

${ }^{11}$ We do not have data on technology contracts involving franchising agreements, use of trademarks, know-how and technical services but not involving patent licensing.
} 
Each technology contract is identified by a unique identifier (processo), which typically has several documents registered at INPI over time (certificado). We consider the first time a document related to a given contract is registered at INPI as its date of registration. Further documents registered in relation to a given contract tend to correspond to corrections or additions to the first certificate, very frequently because in the first document the agreement referred to patent applications that were later granted and the event of the grant had to be reported, notably because patent licensing payment information is only declared for licensing contracts involving granted patents.

INPI technology contract data allow us to identify the date of registration at INPI of all the different certificados corresponding to the same contract; the IPRs covered; whether the contract involves the transfer of other technological knowledge not protected by IPRs (i.e. know-how, scientific and technical services); the licensor and licensee's names; the country of origin of the licensor; the industrial classification of the Brazilian licensee's main activity (CNAE/IBGE) and the exploitation conditions agreed in the contract (e.g. exclusive or not, contract term, payment schemes). We distinguish licensing contracts involving affiliated parties from contracts not involving affiliated parties. We identify affiliated parties firstly based on name similarity, and when licensor and licensee have different names we rely on Internet searches for company websites, press releases and any other relevant information source available. We consider that the licensor and the licensee are affiliated when we find that they belong to the same company group, are involved in a joint venture, merger or acquisition.

INPI contract data also has information about the payment scheme and fees agreed, however the value of the fees itself is not very informative because of the regulations in place. The Brazilian tax income law states that only royalty rates up to a threshold of 5 percent of net sales price would be eligible for tax deduction in contracts among unaffiliated parties, and that is also the maximum amount of royalties permitted in contracts between foreign affiliated companies. ${ }^{12}$ To abstract from these issues, following the works of Cebrian (2009) and Hegde (2014) we codify different payment

\footnotetext{
${ }^{12}$ The limit of 5\% (five percent) of the net sales price of the product or service related to technology is relative to the tax deduction of expenditure on technology. Contracts should establish remuneration in accordance with the values prevailing in the market. For contracts between companies that have major capital, some market levels need to be respected and these maximum coefficients are established by the tax legislation Ordinance MF. 436/58 supported by art. 12 of Law No. 4.131/62 in accordance with the article 50 of Law no. 8.383/91 (1991).
} 
schemes, without analyzing the value of the fees itself. We thus distinguish three types of contracts: (i) involving only upfront payments (one off lump-sum up front payment); (ii) two-part tariffs, combining fixed and variable fees, or periodical fixed fees; and (iii) variable payments, involving only royalty payments (stipulating as payment a percentage of the net sales or of the final price). ${ }^{13}$

Finally, we link parsed patent numbers from INPI contract data to patent level information (e.g. International Patent Classes (IPC), number of inventors, patent family size) from data contained in PATSTAT October 2012 edition. We also used BADEPI10, the patent statistics database prepared by INPI in cooperation with WIPO (Barcelos et al. 2014), to get information on patents filed by licensors and licensees at INPI since 2000 (first year available in the database), by matching the names of companies with names of patent applicants in BADEPI10, taking into consideration variations in the names of firms, and applicant IDs when available. As noted earlier, as there is no data available on patent citations for INPI patents (neither in PATSTAT nor in BADEPI10), we cannot therefore include citations-based variables in the main analysis at the contract level. We rely on citation data for the EPO patent family members of the patents included in the agreements in additional analyses that we perform on a subsample, as we explain below.

Between 1996 and 2012, INPI registered 660 domestic and foreign technology contracts. They all involve the licensing of patents, utility models or industrial designs filed in Brazil (580 involve at least one patent), 106 include also the use of trademarks and 172 the provision of know-how or scientific and technical assistance. ${ }^{14}$ After retaining contracts for which we have identified the legal relationship between parties (affiliates or unaffiliated), we have 498 foreign technology contracts involving patent licensing, around $75 \%$ of the total. About half of these contracts (53\%) consist of standalone patent licensing agreements (see Table 1) and the rest (46\%) are technology packages (providing licensing of other IPRs); 35\% include the transfer of know-how

\footnotetext{
${ }^{13}$ Contract duration is also limited by law to a maximum of five years, renewable another five years, so using this data to analyze the effect of know-how on the duration of licensing agreements is not very useful either.

${ }^{14}$ In a descriptive study of technology transfer contracts registered at INPI in the period 2001-2006, Rocha Amorim and Gomez de Souza (2011) show that licensing of patents, industrial designs or utility models (EP contracts) represent only 2.5 percent of all technology contracts registered at INPI. They report the distribution across categories being as follows: $15 \%$ of contracts contain use of trademarks; $13 \%$ provide technology supply; $64 \%$ include scientific and technical assistance and, $6 \%$ refer to a mixed category where two or more of types of transfer are combined in a single contract. Our sample includes the latter group plus stand-alone patent licensing contracts.
} 
(FT or SAT) and $21 \%$ involve the use of trademarks (10\% in combination with FT or SAT). The share of contracts with know-how transfer here reported is close to the one found by Zuniga and Guellec (2009) for a segment of firms in a survey study on European and Japanese firms, where a third of patenting firms reported that know-how was involved in 40 percent of their patent licensing deals whereas for Japanese firms only a sixth of firms report such a frequency.

Table 1: Types of Patent Licensing Contracts (Involving a Foreign Company Licensor)

\begin{tabular}{cccc}
\hline & With Affiliates & With Unaffiliated & Total \\
\hline Stand-Alone & 129 & 127 & 256 \\
Combined (with IPR bundles) & 127 & 94 & 221 \\
Total of Contracts & $\mathbf{2 5 6}$ & $\mathbf{2 2 1}$ & $\mathbf{4 7 7}$ \\
With Know-how* & 100 & 68 & 168
\end{tabular}

Note: Combined are patent licensing contracts involving the licensing of other intellectual property rights (EPC -combined). * With Know-how: Contracts that include licensing of non-IPR protected technology or the provision of SAT (scientific or technical services). 
Table 2: Main Contract Features of International Patent Licensing Contracts

\begin{tabular}{|c|c|c|c|c|c|}
\hline \multirow[b]{2}{*}{ Variable } & \multirow[b]{2}{*}{ Description } & \multicolumn{2}{|c|}{ With Affiliated } & \multicolumn{2}{|c|}{$\begin{array}{c}\text { With } \\
\text { Unaffiliated }\end{array}$} \\
\hline & & Obs. & Mean & Obs. & Mean \\
\hline \multicolumn{6}{|l|}{ Contract features } \\
\hline Exclusive license & $\begin{array}{l}\text { Dummy equal to one if the contract } \\
\text { includes exclusivity restrictions }\end{array}$ & 256 & 0.35 & 221 & 0.31 \\
\hline IPR bundle & $\begin{array}{l}\text { Dummy equal to one if the contract } \\
\text { includes licensing of trademarks, } \\
\text { industrial designs or utility models in } \\
\text { addition to patent licensing }\end{array}$ & 256 & 0.31 & 221 & 0.22 \\
\hline Trademark & $\begin{array}{l}\text { Dummy equal to one if the contract } \\
\text { includes licensing of trademarks }\end{array}$ & 256 & 0.22 & 221 & 0.20 \\
\hline Design/Models & $\begin{array}{l}\text { Dummy equal to one if the contract } \\
\text { includes licensing of industrial designs or } \\
\text { models }\end{array}$ & 256 & 0.13 & 221 & 0.03 \\
\hline \multicolumn{6}{|l|}{ Payment scheme } \\
\hline Upfront payment only & $\begin{array}{l}\text { Dummy equal to one if the contract } \\
\text { requires only an upfront payment. }\end{array}$ & - & - & 158 & 0.19 \\
\hline Combined payment & $\begin{array}{l}\text { Dummy equal to one if the contract } \\
\text { requires both lump-sum and royalty } \\
\text { payments (two part tariffs) or periodical } \\
\text { fixed fees }\end{array}$ & - & - & 158 & 0.47 \\
\hline Royalty payment only & $\begin{array}{l}\text { Dummy equal to one if the contract } \\
\text { requires only royalty payments (tied to } \\
\text { the licensee's revenues). }\end{array}$ & - & - & 158 & 0.34 \\
\hline
\end{tabular}

Note: We only analyze payment schemes for technology contracts with unaffiliated parties. We categorized payment types in three schemes: upfront payment only, combined payment (having an upfront payment and a royalty) and royalty only. This classification was only possible for contracts declaring payment type. Only 158 contracts contained payment information. ${ }^{15}$

From Table 2, data indicates that patent licensing with affiliates contain more frequently other forms of technology transfer (in addition to licensing of patents) than with unaffiliated firms: 39 percent of contracts with affiliates involve know-how transfers whereas in contracts with unaffiliated parties this figure is 31 percent. In terms of licensing of other intellectual assets, contracts with affiliated firms in Brazil exhibit higher propensities to involve also licensing of industrial designs or models as well as a higher rate of licensing of trademarks compared to contracts with unaffiliated companies. 23 percent of contracts with affiliates also include trademark licensing and 18 percent report licensing of industrial designs or utility models -these figures are 20 and 7 percent in the group of contracts with unaffiliated firms. In contrast, the share of contracts with exclusivity clauses is very similar in both groups: 35 and 36 percent of contracts, respectively for licensing with affiliates and unaffiliated.

\footnotetext{
${ }^{15}$ Contracts with missing data on payments (payment market as "nihil") are those which only include pending patents, for which payment terms are then gradually added as patents get granted.
} 
Table 3 shows suggest noteworthy differences across industries in the importance of know-how transfer or licensing of other IPRs in patent contracts. Table 3 displays the frequency of these transactions for ten economic industries (main economic industry of operation of the Brazilian licensee as recorded at the Department of Technology Transfer of INPI). Food and beverages, followed by basic metallurgy and chemicals \& fuels are the three most important licensee industries with know-how transfer whereas Wood and Paper, followed by Rubber and Plastics, and Others are the licensee industries with highest rates of licensing of other IPRs. The same patterns are reported for the sample of licensing contracts between unaffiliated parties.

Table 3: Patent Licensing Contracts involving Know-how and Licensing of other IPRs (IPR bundle)

\begin{tabular}{|c|c|c|c|c|c|c|}
\hline \multirow{3}{*}{ Economic Sector (domestic licensee) } & \multicolumn{2}{|c|}{ All contracts } & \multicolumn{4}{|c|}{ With Unaffiliated } \\
\hline & $\begin{array}{l}\text { Know- } \\
\text { How }\end{array}$ & $\begin{array}{l}\text { IPR } \\
\text { bundle }\end{array}$ & & $\begin{array}{l}\text { Know- } \\
\text { How }\end{array}$ & IPR bundle & \\
\hline & Mean & Mean & Obs. & Mean & Mean & Obs. \\
\hline Basic metallurgy & 0.41 & 0.27 & 22 & 0.57 & 0.14 & 7 \\
\hline Chemicals and fuels & 0.38 & 0.21 & 143 & 0.48 & 0.11 & 63 \\
\hline Food and beverages & 0.52 & 0.3 & 27 & 0.60 & 0.40 & 5 \\
\hline Machines and equipment & 0.26 & 0.36 & 190 & 0.20 & 0.41 & 74 \\
\hline Metallic and non-metallic miner. & 0.10 & 0.40 & 50 & 0.08 & 0.25 & 12 \\
\hline Motor vehicles & 0.32 & 0.34 & 41 & 0.33 & 0.33 & 9 \\
\hline Other & 0.09 & 0.41 & 46 & 0.11 & 0.11 & 18 \\
\hline Rubber and plastic & 0.19 & 0.43 & 53 & 0.22 & 0.11 & 9 \\
\hline Trade and services & 0.16 & 0.39 & 62 & 0.11 & 0.26 & 19 \\
\hline Wood and paper & 0.2 & 0.52 & 25 & 0.2 & 0.47 & 15 \\
\hline Total & 0.27 & 0.34 & 667 & 0.29 & 0.26 & 233 \\
\hline
\end{tabular}

The data relating to contracts registered at INPI should not be considered a census of transactions in technology. As explained by the Department of Technology Transfer at INPI, it is difficult to know how many contracts are not recorded and thus estimate the real size of the technology contract market in Brazil. Examples of contracts not registered may include the service provision of scientific and technological research conducted among residents, offset agreements, agreements for technological cooperation, technology transfer operations involving no direct compensation for intangible assets and technology exports, among others. As general practice, as long as there are no remittances abroad taking place, mandatory registration does not apply. 
Purely domestic transactions, between domestic companies (or entrepreneurs) are thus poorly covered in the data ${ }^{16}$.

\section{Empirical analysis}

We employ probit models to examine the hypotheses previously exposed. We relate the decision to provide know-how $\left(y_{1 i}\right)$ to the variables proposed in the literature $\left(x_{1 i}\right)$ and hypothetically to the provision of complementary technology inputs such as other IPRs (trademarks) $\left(y_{2 i}\right)$ :

$$
y_{1 i}=I\left(\alpha_{1} y_{2 i}+\beta_{1} x_{1 i}+u_{1 i}\right)
$$

where $I$ is an indicator function that takes the value of 1 when its argument is true and 0 otherwise. Our dependent variable is equal to 1 if the contract includes knowhow transfer terms:

$$
\operatorname{Pr}\left(y_{1 i}=1\right)=\beta_{1} x_{1 i}+\alpha y_{2 i}+u_{1 i}
$$

Taking the contract (processo) as the unit of analysis and consolidating patentlevel indicators at the contract level, we relate the probability of the contract to include know-how transfer to the following explanatory variables: $i$ ) contractual features (dummy equal to one if the contract explicitly contains know-how transfer; dummy equal to one if it has exclusivity restrictions and different types of payment scheme (upfront lump-sum payment only, royalty rates only or combined schemes, including two part tariffs or periodical fixed fees) - see Annex Table A1 for more information about different types of payments; ii) IPR bundle (patents, trademarks industrial designs, utility models); a dummy equal 1 indicating whether the contract involves licensing of other IPRs in addition to patents; iii) country of licensor (a dummy indicating if United States, Germany, France or another country are the countries of origin of the licensor) ${ }^{17}$; iv) industrial sector of the Brazilian licensee (grouping together different CNAE/IBGE 1.0 2-digit classes in broader areas, as set out in Annex table A2); and, lastly, v) technology features of the licensed patents, such as number of IPC classes, number of inventors; diffusion lag (number of years between average filing year of licensed patents and year of contract registration) and number of patents

\footnotetext{
${ }^{16}$ They correspond to 162 contracts in the INPI database for the period considered, which are consequently excluded from our empirical analysis which is focused on cross-border contracts.

${ }^{17}$ US, Germany and France are the top three countries in the sample, each with more than $10 \%$ of the contracts. Japan, Netherlands, Switzerland and Italy follow with 6\%, 6\%, 5\% and 4\% respectively. The remaining countries have lower shares.
} 
licensed per contract (likely to be related to the complexity of the transferred technology).

The number of inventors has been used as an indicator of the cost of invention and it has often been found to be a good proxy for the economic value of patents and their quality (Gambardella et al 2007; OECD 2009). In a group of regressions, we also include a dummy called "biadic family" indicating the presence of patents also filed at USPTO and EPO (i.e. the INPI patent filing listed in the technology contract belongs to a family with USPTO and EPO filings). This is an additional dummy to distinguish quality patents and evaluate the link between technology of high quality and know-how licensing. ${ }^{18}$ Belonging to a triadic patent family have been found to be good indicator of the market potential of the patented technology in question and to be positively correlated to the economic value of the invention and its quality (van Zeebroeck, 2008). The number of different IPC classes relates to the scope of technology, that is, the different technology areas that are protected and in which that invention could be used. Previous studies indicate that patent breadth is associated with more effective protection and so we expect the average scope of patents in contracts to be positively associated to the provision of know-how. Patent scope is also an indication of how much transversal such technology is (Lerner 1994; Lanjouw and Schankerman 2001) and it has also been found to be related to (higher) quality inventions (Lerner, 1994). The diffusion lag, defined as the average number of years between filing of the licensed patents and contract year, gives an indication of the novelty of the technology at the time of the licensing agreement.

We control for the licensee's industrial sector (the licensor's industrial sector is not registered in our contract data), contracting time (year of contract registration at INPI, defined as year of earliest date of registration of a certificado related to a given processo), and the licensor's country of origin (Germany, US, France and others). We also control for licensor's and licensee's size of patent portfolios and existence of a prior relationship. The variable "prior relationship" is a dichotomous variable which is equal to one if the two parties had prior relationships through patent licensing contracting, as observed in our data. The coefficient of this dummy variable indicates

\footnotetext{
${ }^{18} \mathrm{We}$ have also tested the average number of INPI patents in triadic families (including USTPO, EPO and JPO filings, see OECD 2009 and Martinez 2011) but we detected high multicollinearity between this variable, on the one hand, and number of inventors and number of IPCs, on the other. We also tried average number of INPI patents in biadic families (with USPTO and EPO filings) and results were similar to the biadic family dummy that we finally included in the analysis.
} 
the probability differential of having know-how for contracts involving partners with past contracting experience with respect to first time contracts. We report results from probit regressions for two types of contracts: (i) contracts involving only affiliated parties; and (ii) contracts involving only not affiliated parties.

Our analysis suffers from several limitations. We do not dispose of company data and therefore we cannot control for firm features such as firm size (in terms of employees or sales), downstream capacity (manufacturing and distribution assets), or R\&D investment (or stock) of licensors and licensees. As regards industry or market variables, we are only able to identify the licensee's industry affiliation as declared to INPI. We are nevertheless able to control for technological strength of firms (for a subsample of contracts) and prior licensing relationships as recorded in our contract data. Unfortunately data allowing the tracking of patent portfolios are only available from 2000 onwards. As a proxy of the technological strength of companies we use firms' patent portfolio. This is the number of patent applications filed at the INPI from 2000 (directly or through the PCT route) to the year when the contract was signed.

There are many other aspects of technology licensing agreements that in reality can also affect the trade-offs examined but are beyond the scope of this paper, mainly because of lack of the necessary micro-data at the level of contracts or, at least, technology areas or industrial sectors The characteristics of the optimum contract depend on a number of factors such as market (and technology) competition, reputation, involvement of intangibles like brand and loyalty, and the ability to enforce the contract in court. We also recognize that our sample of patent licensing contracts does not represent the totality of technology transfers. Exchanges of technology may also occur without patents, particularly in contexts where patent protection is weak and could lead to imitation by local firms. As recurrently shown by survey studies not all inventions are patented (e.g. Levin et al., 1987; Cohen et al., 2000) and MNEs may not patent all their inventions in Brazil and prefer to commercialize technology or certain types of technology through know-how or contracting services not involving patents. The backlog of the Brazilian patent office is known to be one of the highest and this contributes to multinational companies' reticence to patent in Brazil (Barcelos et al., 2014). The legal uncertainty derived from having patents filed in Brazil but not granted for many years (10 years on average), which is more than in other countries, may have a 
negative effect on the likelihood of firms seeking protection in the country, at least for some of their inventions.

Another caveat we should mention is our impossibility to track ownership changes (mergers and acquisitions) in firms over time. We have been able only to see only the current legal status of firms (acquired or merged or continuing alone). We do not have sufficient information on previous firm legal relations and we prefer to be as conservative as possible, considering $\mathrm{M} \& \mathrm{~A}$ as a sign of being or planning to be 'affiliates'. We recognize though the importance of tracking M\&A changes dynamically in the analysis of contract features and how they were designed (which occurred in the past) before a local firm is acquired.

Finally, we are unable to evaluate the relationship between know-how and the amount of payments. First, royalty rates used to have a legal threshold (up to $5 \%$ of sales) and therefore there is not sufficient variation in this variable; and second, information on lump-sum amounts is often missing or partially reported.

\section{Results}

\subsection{The Probit Model}

Table 4 displays the explanatory variables, their definition, number of observations and means for the total sample of 477 international contracts registered at INPI between 1996 and 2012 involving patent licensing agreements: 256 contracts between affiliated companies and 221 between unaffiliated firms. Table 5 reports marginal effects for Probit regressions of the likelihood of including know-how transfer in the international technology contracts with patent licensing for each of the subsamples. The unit of analysis is the international technology contract with patent licensing. Columns (1) to (5) display regressions for contracts involving only affiliated companies (e.g. belonging to the same multinational company group) whereas columns (6)-(12) report regressions for contracts involving unaffiliated domestic firms. Columns (4)-(5) and (11)-(12) control for the technological strength of partner companies, as approximated by the patenting stock of firms. Given the limited availability of patent data harmonized at the applicant level from INPI (BADEPI10 starts with 2000 filings) these regressions refer only to contracts signed between 2000 and 2010. We discuss next the results for each of our groups of variables, compare findings across the two samples and relate our hypotheses mostly to the results of the regressions on contracts between un-affiliated 
parties. The analysis of payment types is only conducted in the sample of contracts involving unaffiliated companies.

Table 4: Variable definitions and descriptive statistics of international patent licensing contracts

\begin{tabular}{|c|c|c|c|c|c|}
\hline \multirow[t]{2}{*}{ Variable } & \multirow[t]{2}{*}{ Definition } & \multicolumn{2}{|c|}{$\begin{array}{c}\text { With } \\
\text { Affiliated }\end{array}$} & \multicolumn{2}{|c|}{$\begin{array}{c}\text { With } \\
\text { Unaffiliated }\end{array}$} \\
\hline & & Obs. & Mean & Obs. & Mean \\
\hline \multicolumn{6}{|l|}{ Technology features* } \\
\hline Patents nbr & Number of licensed patents & 256 & 18.73 & 221 & 6.32 \\
\hline IPC nbr & $\begin{array}{l}\text { Average number of } 4 \text { digit IPC classes of } \\
\text { the licensed patents }\end{array}$ & 256 & 1.91 & 221 & 1.98 \\
\hline Inventors nbr & $\begin{array}{l}\text { Average number of inventors of licensed } \\
\text { patents }\end{array}$ & 256 & 2.44 & 221 & 2.22 \\
\hline Diffusion lag & $\begin{array}{l}\text { Number of years between average filing } \\
\text { year of the licensed patents and contract } \\
\text { year of registration. }\end{array}$ & 256 & 7.72 & 221 & 8.01 \\
\hline Biadic family & $\begin{array}{l}\text { Dummy equal to } 1 \text { if the licensed INPI } \\
\text { patent(s) included in the technology } \\
\text { contract belong to an extended } \\
\text { (INPADOC) family with EPO and } \\
\text { USPTO members (i.e. patents also filed } \\
\text { at EPO and USPTO). }\end{array}$ & 256 & 0.86 & 221 & 0.81 \\
\hline \multicolumn{6}{|l|}{ Firm Features } \\
\hline & $\begin{array}{l}\text { Sum of patent applications to INPI } \\
\text { (directly or via PCT) from } 2000 \text { up to the }\end{array}$ & & & & \\
\hline Licensor's patent portfolio & $\begin{array}{l}\text { date of contract } \\
\text { Sum of patent applications to INPI } \\
\text { (directly or via PCT) from } 2000 \text { up to the }\end{array}$ & 186 & 200.44 & 173 & 110.24 \\
\hline Licensee's patent portfolio & $\begin{array}{l}\text { date of contract } \\
\text { Dummy equal to one if partners had a } \\
\text { patent licensing contract in the past }\end{array}$ & 186 & 200.44 & 173 & 74.34 \\
\hline Prior relations & $\begin{array}{l}\text { (limited for the years and contracts } \\
\text { observed in the sample, 1996-2012) }\end{array}$ & 256 & 0.34 & 221 & 0.14 \\
\hline \multicolumn{6}{|l|}{ Country of foreign licensor } \\
\hline United States & $\begin{array}{l}\text { Country of origin of licensor is United } \\
\text { States }\end{array}$ & 256 & 0.45 & 221 & 0.27 \\
\hline France & Country of origin of licensor is France & 256 & 0.12 & 221 & 0.19 \\
\hline Germany & Country of origin of licensor is Germany & 256 & 0.16 & 221 & 0.09 \\
\hline \multicolumn{6}{|c|}{ Industrial sector of Brazilian licensee ${ }^{* *}$} \\
\hline $\begin{array}{l}\text { Chemicals, fuels, rubber } \\
\text { and plastics }\end{array}$ & $\begin{array}{l}\text { CNAE/IBGE classes } 23 \text { and } 24 \text { and } \\
\text { CNAE/IBGE class } 25 \text {, }\end{array}$ & 256 & 0.30 & 221 & 0.31 \\
\hline $\begin{array}{l}\text { Machines, equipment, } \\
\text { vehicles }\end{array}$ & $\begin{array}{l}\text { CNAE/IBGE classes } 29,30,31,32 \text { and } \\
33 \text { and CNAE/IBGE classes } 34 \text { and } 35 \\
\text { CNAE/IBGE classes } 26 \text { and } 28 \text { and }\end{array}$ & 256 & 0.34 & 221 & 0.37 \\
\hline Minerals and metallurgy & CNAE/IBGE class 27 & 256 & 0.13 & 221 & 0.09 \\
\hline
\end{tabular}

Note: * Based on matching INPI patent numbers mentioned in the technology contracts with numbers of INPI filings from PATSTAT Oct. 2012. ** See correspondence between these broad industrial and the original CNAE/IBGE classes in Annex Table A2.

\section{Contracts between affiliated parties}

Contract features do not appear to be associated with the inclusion of know-how transfer in contracts signed between affiliated parties. Indeed, contracts involving IPR bundling (a dummy equal to one indicates the presence of licensing of trademarks, 
industrial designs or utility models) are weakly associated to a higher probability of know-how provision than the rest of contracts (regressions 2 and 3), but the effect vanishes when we control for the parties' patent portfolio (regressions 4 and 5).

The transfer of know-how is related to younger technologies: the coefficient for the (average per contract) diffusion lag is negative, indicating that the more novel the technology the more likely is the provision of know-how (regressions 1 to 5). The coefficients of variables reflecting the quality of inventions show mixed findings. Technologies with a higher number of inventors -which proxies for the costs of R\&Dare not significantly related to a higher likelihood of know-how provision. This suggests that know-how transfer among affiliates is not associated to the licensing of more resource intensive technologies (with higher $R \& D$ costs). On the other hand, the coefficient on the dummy biadic family (patents also filed at USPTO and EPO) is positive and significant. The three variables - patent scope, number of inventors and patent family size - reflect quality of technology (van Zeebroeck 2011). With regards to other technology features, we also find that patent scope and family size are positively related and patent age negatively related to know-how transfer with patent licensing among affiliates. Know-how transfer shows a positive correlation with the scope of technology, as measured by the average number of IPCs in the patents licensed. This result is valid across regressions and holds with the inclusion of additional variables (regressions 1 to 5). Thus, the likelihood of the provision of know-how increases when patented technology is broader and more transversal.

In a nutshell, intra-group patent licensing contracts are more likely to include know-how transfer when technologies are younger, broader and more valuable in terms of international market potential. We also find that having or not an exclusive license on the patented inventions is not related either to the probability of including know-how transfer. Finally, as we find that past relationships (a dummy equal to one if partners had a patent licensing contract in the past; limited to the timeframe observed in our sample), are positively associated to the probability of having know-how transfer. This may simply indicate that even within the network of multinationals, international knowledge transfer benefits from repeated interactions within affiliated firms, especially if they are located in an emerging country (Brazil). ${ }^{19}$

\footnotetext{
${ }^{19}$ We have not evaluated the type of payment scheme in the sample of contracts with affiliated firms, for two reasons. First, by law, intra-firm lump-sum payments are not allowed (given the loopholes in intra-firm
} 


\section{Contracts between un-affiliated parties}

Based on the findings of previous empirical and theoretical studies, we expect contracts with patent licensing between unaffiliated parties that also involve knowtransfer to show distinctive features to those that do not involve know-how transfer. More precisely, as hypothesized earlier, we expect them to be more likely to include the licensing of additional IPRs (notably trademarks); to have upfront lump sum payments; to cover younger and higher quality technologies; and to involve parties with prior relations.

The first hypothesis is confirmed. We find that contracts with IPR bundles are positively associated to know-how transfer. The presence of this feature in the contract is associated to a probability of having know-how assistance ranging between 20 and 46 percent higher than for contracts without IPR bundles, and this effect remains when we control for firms' patent portfolios.

Contracts with know-how transfer are also more likely to be associated to oneoff upfront payments alone than to royalty payments alone (category of reference), confirming our second hypothesis. This result is significant only in regressions (11) and (12) when we control for the parties' patent portfolios - as a proxy for their technological strength. The sample here is however reduced to 114 observations. This finding is in line with Mendi (2007) and Bessy et al. (2010), in spite of our differences in terms of samples and types of contracts. ${ }^{20}$ As in Mendi, upfront payments are positively related to know-how transfer. In our case, contracts with upfront payment have a probability 50 percent higher to include know-how than contracts having only royalty as payment type. Two-part payments, in contrast, are less associated with knowhow compared to payments based on royalty payments only. We could argue that upfront payments illustrate licensor's maximum precaution in the transfer of nonprotected tacit knowledge.

transfer prices), and second, because the economic logic may be different and payment may not necessarily reflect pricing strategies associated to moral hazard but rather international fiscal strategies and transfer pricing.

${ }^{20}$ Bessy et al (2010) find a strong positive association between lump-sum payment (and negative relation associated to royalty payment) and know-how provision in French technology licensing agreements by French firms. 
Table 5: Probit Model Estimates-Dependent variable: Know-how Provision in international technology contracts with patent licensing

\begin{tabular}{|c|c|c|c|c|c|c|c|c|c|c|c|c|}
\hline & \multicolumn{5}{|c|}{ With Affiliated } & \multicolumn{7}{|c|}{ With Un-Affiliated } \\
\hline & (1) & (2) & (3) & (4) & (5) & (6) & (7) & (8) & (9) & (10) & (11) & (12) \\
\hline \multicolumn{13}{|l|}{ Technology features } \\
\hline \multirow[t]{2}{*}{ IPC4 nbr (log) } & $0.439 * * *$ & $0.459 * * *$ & $0.457 * * *$ & $0.400 * *$ & $0.353 *$ & -0.0443 & -0.0193 & -0.0302 & -0.120 & -0.114 & -0.0682 & 0.0493 \\
\hline & $(0.150)$ & $(0.151)$ & $(0.153)$ & $(0.198)$ & $(0.198)$ & $(0.116)$ & $(0.116)$ & $(0.116)$ & $(0.173)$ & $(0.177)$ & $(0.174)$ & $(0.181)$ \\
\hline \multirow{2}{*}{ Inventors nbr (log) } & 0.171 & 0.153 & 0.163 & 0.152 & 0.172 & 0.0637 & 0.0713 & 0.0376 & 0.221 & 0.225 & 0.265 & 0.441 \\
\hline & $(0.120)$ & $(0.123)$ & $(0.121)$ & $(0.147)$ & $(0.147)$ & $(0.138)$ & $(0.140)$ & $(0.140)$ & $(0.173)$ & $(0.173)$ & $(0.213)$ & $(0.284)$ \\
\hline \multirow[t]{2}{*}{ Diffusion lag (log) } & $-0.188 * *$ & $-\mathbf{0 . 1 8 8} * *$ & $-0.182 * *$ & $-0.407 * * *$ & $-\mathbf{0 . 4 5 8} * * *$ & -0.110 & -0.0990 & $-0.131 *$ & $-0.641 * * *$ & $-0.638 * * *$ & $-0.818 * * *$ & $-\mathbf{0 . 8 8 2} * * *$ \\
\hline & $(0.0790)$ & $(0.0813)$ & $(0.0810)$ & $(0.122)$ & $(0.136)$ & $(0.0715)$ & $(0.0744)$ & $(0.0759)$ & $(0.166)$ & $(\mathbf{0 . 1 7 3})$ & $(0.211)$ & $(\mathbf{0 . 1 8 6})$ \\
\hline \multirow{2}{*}{ Patents nbr (log) } & -0.00767 & -0.0262 & -0.0248 & -0.0146 & -0.0461 & -0.0520 & -0.0460 & -0.0645 & $-0.169 * *$ & $-0.167 * *$ & $-0.274 * * *$ & $-0.255 * * *$ \\
\hline & $(0.0297)$ & $(0.0320)$ & $(0.0322)$ & $(0.0410)$ & $(0.0420)$ & $(0.0580)$ & $(0.0566)$ & $(0.0600)$ & $(0.0713)$ & $(0.0756)$ & $(0.0825)$ & $(0.0903)$ \\
\hline \multirow[t]{2}{*}{ Biadic Family (dummy=1) } & & & & & $0.341 * * *$ & & & & & -0.0177 & & $-0.460 *$ \\
\hline & & & & & $(0.0738)$ & & & & & $(0.195)$ & & $(0.263)$ \\
\hline \multicolumn{13}{|l|}{ Contract Features } \\
\hline \multirow[t]{2}{*}{ IPR bundle } & & $0.164 *$ & $0.163 *$ & 0.115 & 0.113 & & $0.216 *$ & $0.213^{*}$ & $0.361 * *$ & $0.361^{* *}$ & $0.437^{* *}$ & $0.460 * * *$ \\
\hline & & $(0.0867)$ & $(0.0861)$ & $(0.108)$ & $(0.106)$ & & $(0.124)$ & $(0.128)$ & $(0.162)$ & $(0.162)$ & $(0.187)$ & $(0.177)$ \\
\hline \multirow[t]{2}{*}{ Exclusive license } & & & 0.0564 & 0.0928 & 0.0961 & & & $-0.153^{*}$ & -0.180 & -0.179 & -0.157 & -0.152 \\
\hline & & & $(0.0909)$ & $(0.115)$ & $(0.115)$ & & & $(0.0866)$ & $(0.114)$ & $(0.116)$ & $(0.129)$ & $(0.134)$ \\
\hline \multicolumn{13}{|c|}{ Payment scheme (reference: Royalty only) } \\
\hline \multirow[t]{2}{*}{ Upfront payment only } & & & & & & & & & 0.275 & 0.273 & $0.518 * * *$ & $0.495 * * *$ \\
\hline & & & & & & & & & $(0.179)$ & $(0.176)$ & $(0.175)$ & $(0.179)$ \\
\hline \multirow[t]{2}{*}{ Combined payment } & & & & & & & & & -0.121 & -0.120 & $-0.293^{* *}$ & $-0.301 * *$ \\
\hline & & & & & & & & & $(0.119)$ & $(0.118)$ & $(0.121)$ & $(0.126)$ \\
\hline \multicolumn{13}{|l|}{ Firm Features } \\
\hline \multirow[t]{2}{*}{ Prior relations } & & $0.263 * * *$ & $0.264 * * *$ & $0.352 * * *$ & $0.389 * * *$ & & -0.106 & -0.109 & -0.0515 & -0.0518 & -0.0740 & -0.0883 \\
\hline & & $(0.0865)$ & $(0.0862)$ & $(0.0904)$ & $(0.0855)$ & & $(0.0875)$ & $(0.0872)$ & $(0.132)$ & $(0.132)$ & $(0.128)$ & $(0.136)$ \\
\hline \multirow[t]{2}{*}{ Licensor's patent portfolio } & & & & 0.0298 & 0.0325 & & & & & & -0.0108 & -0.0114 \\
\hline & & & & $(0.0272)$ & $(0.0266)$ & & & & & & $(0.0343)$ & $(0.0340)$ \\
\hline \multirow[t]{2}{*}{ Licensee's patent portfolio } & & & & & & & & & & & -0.0460 & -0.0488 \\
\hline & & & & & & & & & & & $(0.0401)$ & $(0.0387)$ \\
\hline \multicolumn{13}{|l|}{ Controls } \\
\hline \multirow{2}{*}{$\begin{array}{l}\text { Contract year } \\
\text { Industrial field of licensee }\end{array}$} & yes & yes & yes & yes & yes & yes & yes & yes & yes & yes & yes & yes \\
\hline & yes & yes & yes & yes & yes & yes & yes & yes & yes & yes & yes & yes \\
\hline Licensor's country & yes & yes & yes & yes & yes & yes & yes & yes & yes & yes & yes & yes \\
\hline \multirow{3}{*}{$\begin{array}{l}\text { Pseudo-R }{ }^{2} \\
\text { Wald } \chi^{2} \\
\text { Observations }\end{array}$} & 0.09 & 0.14 & 0.14 & 0.24 & 0.28 & 0.15 & 0.17 & 0.19 & 0.36 & 0.36 & 0.42 & 0.45 \\
\hline & $28.11 * *$ & $40.39 * * *$ & $41.02 * * *$ & $51.72 * * *$ & $59.87 * * *$ & $41.25 * *$ & $43.02 * *$ & $38.89^{* *}$ & $44.30^{* * *}$ & $45.06^{* * *}$ & $66.21 * * *$ & $80.35 * * *$ \\
\hline & 249 & 249 & 249 & 180 & 180 & 188 & 188 & 188 & 149 & 149 & 114 & 114 \\
\hline
\end{tabular}


As the licensor firm discloses tacit information, she would require payment in advance -because once knowledge is disclosed, counterparts could use it for other purposes or terminate the contract any time. In this case, as all contracts last five years the threat might rather be related to misappropriation of information for other economic purposes - not foreseen in the contract. We have looked at several contracts with lump sum payment (upfront payment only), and many of them, notably in chemicals and petrochemicals contain actually large payment amounts occurring at the start of the contract.

In relation to combined payment schemes having a lower probability to be associated to know-how compared to royalty-only schemes, we could argue that the use of royalties is more related to codified knowledge than to tacit knowledge. We differ in this result with Hegde (2014) who finds that combined schemes are related to knowhow. The explanation of the difference with Hegde's analysis relies basically in the type of industries we study and the market orientation of our contracts. While Hegde analyzes technology contracts in biotechnology in the United States -many of these partnerships require licensor's inputs in $\mathrm{R} \& \mathrm{D}$, our contract data concerns mostly provision of technology for traditional industries. Most of the patent licensing activity we observe in our contract database for Brazil does not require involvement of domestic partners in the development of the innovation. We are talking then about already tested and developed technologies that are licensed abroad. In addition, we focus on international patent licensing contracts, while Hegde analyses essentially domestic contracting.

As regards our third hypothesis, we find no relation between the probability of know-how transfer and the nature of the technology; neither the indicator of technology scope nor the number of inventors involved in the patents are significant in any of the regressions. Furthermore, once we control for patent portfolios (columns 11 ad 12), the dummy biadic family shows a negative sign. Licensed technologies that are protected at both the EPO and USPTO ("biadic patents") -an indication of their strength and expected commercial prospects, have almost 50 percent less probability of being accompanied by know-how transfer.

We can conclude then that know-how transfer to unaffiliated companies is more likely to occur when the patents licensed are of lower quality, which goes against our hypothesis but suggests that what matters most is the potential risk of imitation in a 
country such as Brazil given the lengthy pending periods experienced by patents filed at INPI. This may lead foreign firms to license out their best technologies to third parties in Brazil only when they can ensure a clear definition of the limits of the transfer (without know-how).

It is also worth noting that we find a significant and negative correlation between the size of the patent package and the probability of know-how transfer. The magnitude of this negative effect increases in columns (11) and (12) when we control for firms' patent portfolios. Thus, the higher the number of patents licensed as part of a package in the same technology contract, the less likely it is to have know-how transfer, where the number of patents licensed per contract may be related to the complexity of the transferred technology as suggested earlier.

As regards the age of the technology, measured by the years since the patent filing and the date of the contract (diffusion lag), contracts with know-how seem to be related to younger technologies than contracts without. Know-how transfer is thus associated to technologies that are more quickly diffused on markets after their patent filing in Brazil. This finding confirms the second part of our third hypothesis and is in line with Kim (1997) in his study of know-how transfer in Korean firms, who found that the probability of providing technical services decreases with patent age.

In terms of firm features, neither the existence of prior relations (prior contracts signed between the same parties) nor the size of patent portfolios (which correlate with firm size and are a proxy for the technological strength of the partners) are significantly associated with know-how transfer in technology contracts with patent licensing between unaffiliated parties. The first result goes against our fourth hypothesis. Not being relevant to explain know-how transfer to unaffiliated companies and actually showing a negative coefficient is a counterintuitive result. We think that it may be driven by the limitations of our corporate data, our current impossibility to track changes in firm ownership over time as well as the short time period we are obliged to consider to build the portfolios (only after 2000). We consider that this result deserves further investigation and as such should not be considered as conclusive by now.

Lastly, our results also point at differences in the propensity to provide knowhow according to the licensor's country of origin. In results not reported in Table 2 (for sake of space), our regressions show a higher probability of having know-how transfer when the licensor is from the United States and Germany than from other countries. 
This may nevertheless be influenced by the industry composition of licensing agreements by country. United States has more contracts with transfer of know-how than France and Germany; and for those, United States and Germany are more concentrated than France in chemicals than in machines and equipment. Licensing agreements with unaffiliated firms in the chemical sector are more likely to include know-how, which is consistent with the findings of other studies about know-how in chemicals being more easily codifiable and transferrable than in other sectors (e.g. Anand and Khanna, 2000).

We have assumed that covariates are exogenous to the know-how transfer decision. However, there are at least two main reasons why variables such as trademark provision or exclusivity may be endogenous to the provision of know-how. The first is the presence of latent heterogeneous factors (unobservable) that may affect both the probability of having know-how and the probability of licensing other intellectual assets (e.g. trademarks or designs); the second one is the potential simultaneity in the firm's decision to provide know-how and whether or not to accompany such transaction with the licensing of other complementary assets.

As discussed by previous studies (e.g. Anand and Khanna, 2000), contract features may be simultaneously determined. Following Gourieroux et al (1980) and Maddala (1983) we have tried to evaluate this possibility with the use of a recursive bivariate probit model using full information maximum likelihood (FIML). This approach has been proposed to model endogeneity when both the dependent variable and an endogenous covariate are binary. We tested for the endogeneity of trademark licensing and dealt with the potential simultaneity of both decisions (know-how provision and trademark licensing) in contracts already including patent licensing. However, in the sample of contracts between unaffiliated parties we did not have sufficient observations in each of the four possible outcomes and we were unable to use this model and correct for endogeneity. With a larger dataset and with richer information on companies, this issue could be addressed in the future following the approach proposed by Miravete and Pernias (2010).

\subsection{Know-How and Quality of Patents}

Previous results showed that provision of know-how is negatively associated to the complexity of the licensed technology -as reflected in the number of patents 
licensed in each of the contracts - and the market importance of licensed patents approximated by the dummy on biadic patents. In order to dig further into this, we propose an alternative approach in this section.

We want to know whether patents associated to know-how are of higher quality than patents with no such link. We focus on patent licensing transactions with unaffiliated firms. We conduct this analysis for the sample of licensed patents with EPO family members -for which we could relate to forward citation data (Squicciarini et al., 2013) given the lack of citation data for INPI patents. We relate the probability of receiving forward citations (from other patents in the five years after filing) to the characteristics of the invention (patent level) and contract. ${ }^{21} \mathrm{We}$ also examine the relation between know-how and originality, defined as the number of citations made to patents filed previously in a wider range of IPC classes. These exercises, although do not resolve the endogeneity or simultaneity issues for some of the variables, allow us at least to test whether know-how is associated or not to the technological impact of licensed inventions. These alternative approaches serve therefore as robustness checks for the findings previously reported. We control for contract and patent application years as well as sector effects of licensed technologies.

Table 6 presents summary statistics for our sample of patents. Table 7 shows the results of the patent-level estimations for the EPO family members of the INPI licensed patents. Both technological importance, measured by the probability of receiving a forward citation and originality (Squicciarini et al. 2013) appear to be positively correlated with the licensing of other IPRs (IPR bundle). In contrast, the transfer of know-how is not significantly related to none of the patent-level indicators considered, forward citations or originality, in any regression, except in regression (4) where it shows a negative and weakly significant relation with forward citations. Thus, patents with lower number of citations would be more likely to be included in technology contracts with know-how transfer. This would be consistent with the negative sign observed in regression (12) of Table 2 for the dummy biadic family: patents licensed with know-how transfer seem to be of less strength and importance than patents licensed without know-how transfer in Brazil.

${ }^{21} 65$ percent of the patents in this sample did not receive any forward citations in the first five years after filing. That is why we decided to relate know-how to the probability of forward citations. 
Table 6: Summary Statistics for the patent-level analysis with EPO-PCT patent family members of INPI patents licensed to unaffiliated parties in international

\begin{tabular}{|c|c|c|c|c|c|c|c|}
\hline & \multirow[b]{2}{*}{ Definition } & \multicolumn{3}{|c|}{ EPO PCT Patents } & \multicolumn{3}{|c|}{ EPO-PCT Patents with Filing year $>=2000$} \\
\hline & & Obs. & Mean & Std. Dev. & Obs. & Mean & Std. Dev. \\
\hline \multicolumn{8}{|l|}{ EPO-PCT patents* } \\
\hline Forward citations & $\begin{array}{l}\text { Dummy equal to } 1 \text { if the patent has received at } \\
\text { least one citation in the first } 5 \text { years from } \\
\text { publication }\end{array}$ & 759 & 0.12 & 0.32 & 535 & 0.13 & 0.34 \\
\hline Originality & $\begin{array}{l}\text { Closer to } 1 \text { if the patent cites patents from a wider } \\
\text { range of fields, different IPC classes }\end{array}$ & 739 & 0.68 & 0.19 & 519 & 0.68 & 0.19 \\
\hline \multicolumn{8}{|l|}{ Contract-level features $* *$} \\
\hline Know-how & $\begin{array}{l}\text { Dummy equal to } 1 \text { if contract includes know-how } \\
\text { transfer }\end{array}$ & 759 & 0.12 & 0.32 & 535 & 0.08 & 0.27 \\
\hline IPR bundle & $\begin{array}{l}\text { Dummy equal to } 1 \text { if contract includes other IPR } \\
\text { licensing in addition to patents }\end{array}$ & 759 & 0.51 & 0.50 & 535 & 0.59 & 0.49 \\
\hline Exclusive License & $\begin{array}{l}\text { Dummy equal to } 1 \text { if contract includes exclusivity } \\
\text { restrictions }\end{array}$ & 759 & 0.16 & 0.37 & 535 & 0.15 & 0.36 \\
\hline Licensor's patent portfolio at INPI & $\begin{array}{l}\text { Sum of patents filed by the licensor at INPI since } \\
2000\end{array}$ & & & & 535 & 67.09 & 156.05 \\
\hline
\end{tabular}

Note: * From OECD patent quality database July 2013. ** From INPI technology contracts database for the contract features and BADEPI 1.0 for the patent portfolio data. 
Table 7: EPO-PCT Patent family members of INPI licensed to unaffiliated parties

\begin{tabular}{|c|c|c|c|c|c|c|c|c|}
\hline & \multicolumn{4}{|c|}{ Forward citation (Probit) } & \multicolumn{4}{|c|}{ Originality (OLS) } \\
\hline & (1) & (2) & (3) & (4) & (5) & (6) & (7) & (8) \\
\hline \multicolumn{9}{|l|}{ Contract Level features } \\
\hline Know-how & $\begin{array}{c}-0.0401 \\
(0.0306)\end{array}$ & $\begin{array}{c}-0.0583 \\
(0.0560)\end{array}$ & $\begin{array}{l}-0.0397 \\
(0.0467)\end{array}$ & $\begin{array}{c}-\mathbf{- 0 . 0 7 3 3} * \\
(\mathbf{0 . 0 3 8 6})\end{array}$ & $\begin{array}{c}-0.0248 \\
(0.0318)\end{array}$ & $\begin{array}{c}0.0068 \\
(0.0494)\end{array}$ & $\begin{array}{c}-0.0139 \\
(0.0351)\end{array}$ & $\begin{array}{c}-0.0654 \\
(0.0529)\end{array}$ \\
\hline IPR bundle & $0.116 * * *$ & $0.151 * * *$ & $0.195 * * *$ & $0.239 * * *$ & -0.0189 & 0.0350 & 0.0578 & $0.133 * * *$ \\
\hline & $(\mathbf{0 . 0 2 0 8})$ & $(\mathbf{0 . 0 3 0 5})$ & $(0.0509)$ & $(\mathbf{0 . 0 5 3 7})$ & $(0.0358)$ & $(0.0406)$ & $(0.0366)$ & $(0.0447)$ \\
\hline Exclusive License & $\begin{array}{c}0.0372 \\
(0.0383)\end{array}$ & $\begin{array}{c}0.0486 \\
(0.0726)\end{array}$ & $\begin{array}{c}0.0769 \\
(0.0532)\end{array}$ & $\begin{array}{c}-0.0667 * * \\
(0.0275)\end{array}$ & $\begin{array}{l}-0.0209 \\
(0.0278)\end{array}$ & $\begin{array}{c}-0.0249 \\
(0.0511)\end{array}$ & $\begin{array}{l}0.00867 \\
(0.0223)\end{array}$ & $\begin{array}{c}0.0381 \\
(0.0242)\end{array}$ \\
\hline \multicolumn{9}{|l|}{ Firm Features } \\
\hline Licensor's Patent Portfolio & & $\begin{array}{c}0.00651 \\
(0.00473)\end{array}$ & & $\begin{array}{l}-0.0143 * \\
(0.00778)\end{array}$ & & $\begin{array}{l}-0.0134^{*} \\
(0.00679)\end{array}$ & & $\begin{array}{c}0.00413 \\
(0.00514)\end{array}$ \\
\hline Constant & & & & & $\begin{array}{c}0.698 * * * \\
(0.0265)\end{array}$ & $\begin{array}{c}0.698 * * * \\
(0.0512)\end{array}$ & $\begin{array}{c}0.835 * * * \\
(0.0708)\end{array}$ & $\begin{array}{c}0.971 * * * \\
(0.0551)\end{array}$ \\
\hline \multicolumn{9}{|l|}{ Patent-level controls } \\
\hline Technology fields & & & yes & yes & & & yes & yes \\
\hline Filing year & & & yes & yes & & & yes & yes \\
\hline Observations & 759 & 535 & 592 & 440 & 739 & 519 & 739 & 519 \\
\hline R-squared & & & & & 0.004 & 0.030 & 0.27 & 0.32 \\
\hline Pseudo R-2 & 0.05 & 0.07 & 0.22 & 0.28 & & & & \\
\hline Wald $\chi^{2}$ & $37.34 * * *$ & $29.34 * * *$ & $699.09 * * *$ & $3628.28 * * *$ & & & & \\
\hline
\end{tabular}




\section{Discussion and conclusions}

Patents encourage the development of technology markets and facilitate the division of innovative labor across firms and sectors by reducing informational asymmetries and lowering the cost of transactions. In contrast, the transfer of know-how typically exacerbates contractual hazards and discourages firms from sharing such knowledge outside of the corporation. Using information on technology contracts registered at the Brazilian Patent Office between foreign firms and Brazilian firms (affiliated and unaffiliated) that include patent licensing clauses, we have analyzed under what conditions the provision of know-how for unpatented components of the technology is also explicitly included in the contract.

We have tried to nail down factors that make the provision of know-how more likely in foreign patent licensing contracts in Brazil. By confronting some of the main arguments of the literature with individual data from patent licensing contracts, we have aimed to contribute to the scarce statistical evidence on the design of technology contracts available. We have shown that the contractual hazards related to the provision of know-how tend to be alleviated not only by using payment schemes that take account of informational asymmetries but also through the use of IPR bundles. Our results reveal the complexity in contract design and call for further research not only on the features of contracts but also on the repercussions of such decisions. For instance, it would be interesting to investigate whether licensees receiving know-how show a higher innovative performance than those that did not have such knowledge transfer.

Our analysis suffers however from some data limitations, such as small samples and insufficient corporate information about licensees and licensors. It would have been preferable to control for firm size (approximated in our analysis by the patent portfolio of licensors) and test different proxies for technological competences, for instance. Given the limitations of our data, this exercise should be seen as a first examination of firms' patent licensing agreements based on individual contract data. Results should also be interpreted in the context of developing country. In future research, if data are available, we will try to link contract data with business information (i.e. the coverage and contents of currently available corporate databases such as ORBIS seems to be limited for Brazil) and control for key firm characteristics such the absorption capacity of the licensee and whether the multinational firm is located in the country or abroad. 
We would also like to extend this analysis to the totality of technology transfer agreements (patent and non-patent based) so that we can also analyze conditions and motivations driving the joint licensing of patents with know-how as opposed to standalone patent licensing, or stand-alone know-how licensing.

\section{Acknowledgements}

We thank Vitoria Orind, Lia Medeiros, Sergio Paulino, Marina Filgueiras, Ana Claudia Nonato and Mauro Catarino Vieira de Luz at INPI Brazil. We also thank Stéphane Maraut for his help with the creation of the database linking licensed patents with PATSTAT, as well as Itzel Raya, Rocío Zuniga and Kenedy Alva for their help with data codification. The paper has benefitted from valuable comments from Pierre Mohnen, Francesco Lissoni, Stefano Breschi, Ernest Miguelez, Bronwyn Hall, and other participants at the OECD workshop on Knowledge Networks and Markets held in Washington, D. C., November 2011, the MEIDE Conference in Santiago de Chile, November 2013, the PSDM Conference in Río de Janeiro, November 2013, and from a seminar at UNU-MERIT, Maastricht, March 2014. Catalina Martínez acknowledges funding from the Spanish Ministry of Economy and Competitiveness (CSO 2012-32844) and the Regional Government of Madrid (S2015/HUM-3491 PRODECON-CM). 


\section{REFERENCES}

Alvarez, R., Crespi, G. and J. Ramos (2002), The Impact of Licenses on a "Late Starter" LDC: Chile in the 1990s, World Development 30(8): 1445-1460.

Anand, B. and Khanna, T. (2000), The Structure of Licensing Contracts, Journal of Industrial Economics, 48 (1): 103-135.

Arora, A. (1991), The Transfer of Technological Know-how to Developing Countries: Technology Licensing, Tacit Knowledge, and the Acquisition of Technological Capability, PhD Thesis, Stanford University.

Arora, A. and A. Gambardella (1994), The changing technology of technological change: general and abstract knowledge and the division of innovative labour, Research policy, 23 (5): $523-532$

Arora, A. (1995), Licensing Tacit Knowledge: Intellectual Property Rights and the Market for Know-how, Economics of Innovation and New Technology, 4 (1): 41-60.

Arora, A. (1996), Contracting for tacit knowledge: the provision of technical services in technology licensing contracts, Journal of Development Economics, 50 (2), 233-256.

Arora, A. and M. Ceccagnoli (2006), Patent protection, complementary assets,and firms' incentives for technology licensing, Management Science, 52 (2): 293-308.

Arora, A., A. Fosfuri and A. Gambardella (2001), Markets for Technology: the Economics of Innovation and Corporate Strategy, MIT Press, Cambridge, MA.

Arora, A., and A. Gambardella (2010), "The Market for Technology", Vol II. Chapter 15. In Handbook of Economics of Innovation, edited by B. Hall and N. Rosenberg, 641-678, Amsterdam: North-Holland (Elsevier)

Arrow, K.J. (1962), Economic welfare and the allocation of resources for invention" in R.R. Nelson (ed.), The rate and direction of inventive activity: economic and social factors, Princeton, N.J., Princeton University Press.

Aulakh, M., I S Jiang and Sali Li (2013), Licensee technological potential and exclusive rights in international licensing: A multilevel model. Journal of International Business Studies, 44 (7): 699-718

Barcelos, V., Filgueiras Jorge M., Le Feuvre, B., Lopes F., Medeiros Paulino de Carvalho, S., Pinheiro, V., Raffo, J., Ribeiro, L. (2014), The use of intelectual property in Brazil, WIPO Working Paper No. 23.

Borges Barbosa, D. (2012). Technology contracts in Brazil: The Patent Office screening role, Mimeo, May 2012.

Bessen, S. and L. Raskind (1991), An Introduction to the Law and Economics of Intellectual Property, Journal of Economic Perspectives, 5(1): 3-27. 
Bessy, C., Brousseau, E. and S. Saussier (2010), Hazards in transferring knowledge and contractual architecture: the case of payment schemes in technology licensing agreements, Chaire EPPP, IAE-Pantheon-Sorbonne, Discussion Paper Series, 2010-05, http://chaireeppp.org/files_chaire/saussier_paper_edited_-_june_30_-_20101.pdf

Caves, R. E., Crookell, H. and Killing, P.J. (1983), The imperfect market for technology licensing, Oxford Bulletin of Economics and Statistics, 45 (3): 249-267.

Cebrian, M. (2009), The structure of payments as a way to alleviate contractual hazards in international technology licensing, Industrial and Corporate Change, 18 (6): 1135-1160.

Chung, M. Y. and Lee. K. (2015), How Absorptive Capacity is formed in a Latecomer Economy: Different Roles of Foreign Patent and Know-how Licensing in Korea, World Development, 66: 678-694.

Choi. J.P. (2001), Technology transfer with moral hazard, International Journal of Industrial Organisation, 19: 249-266.

Cohen, W. M. \& Richard R. Nelson and John P. Walsh (2000) Protecting Their Intellectual Assets: Appropriability Conditions and Why U.S. Manufacturing Firms Patent (or Not), NBER Working Papers 7552, National Bureau of Economic Research, Inc.

Contractor, F. (1981), International technology licensing: compensation, costs and negotiation, Lexington Books, Lexington, MA.

De Rassenfosse, G. Palangkaraya, A. and E. Webster (2016), Why do patents facilitate trade in technology? Testing the disclosure and appropriation effects, Research Policy,45(7):1326-1336

Dutz, M., Kannebley Jr S., Scarpelli, M. and S. Sharma (2012), Measuring Intangible Assets in an Emerging Market Economy: An Application to Brazil, Vol. 6142, Washington, DC: World Bank Policy, Research Working Paper.

Economides, N. (1998), Trademarks. The New Palgrave Dictionary of Economics and the Law, Peter Newman, Ed..

Fagerberg, J., Srholec, M. and B. Verspagen (2010), Innovation and Economic Development. In B. Hall, \& N. Rosenberg (Eds.), Handbook of the Economics of Innovation. Vol. II. North Holland, p. 833-872.

Ferrero Zucoloto, G., P. Alves and D. Guerra Fioravante (2013), Intellectual Property and Socio-economic Development Country Study Brazil, WIPO Committee on Development and Intellectual Property (CDIP) Eleventh Session, Geneva, May 13 to 17, 2013, available at http://www.wipo.int/edocs/mdocs/mdocs/en/cdip_11/cdip_11_inf_3.pdf (accessed 10 April 2015).

Gallini, N. and B. Wright (1990), Technology Transfer under Asymmetric Information, The RAND Journal of Economics, 21 (1): 147-160 
Gambardella, A., P. Giuri and A. Luzzi (2007), The Market for Patents in Europe, Research Policy, 36 (8): 1163-1183.

Griffith, R., Redding, S. and J. Van Reenen (2004), Mapping the Two Faces of R\&D: Productivity Growth in a Panel of OECD Industries, Review of Economics and Statistics, 86(4): 883-895

Gourieroux, C., Laffont, J. J. and A. Monfort (1980), Coherency Conditions in Simultaneous Linear Equation Models with Endogenous Switching Regimes, Econometrica, 48(3): 675-95.

Hegde, D. (2014), Tacit Knowledge and the Structure of License Contracts: Evidence from the Biomedical Industry, Journal of Economics and Management Strategy, 23 (3): 568-60.

Helmers, C. and Schautschick, P. (2013), The use of intellectual property right bundles by firms in the UK, Intellectual Property Office, UK.

IMF (2011), World Economic Outlook Database, September 2011

Jensen, R. and Thursby, M. (2001), Proofs and prototypes for sale: the licensing of university inventions, American Economic Review, 91 (1): 240-259.

Jensen, P. H., Palangkaraya, A. and Webster, E. (2015), Trust and the market for technology, Research Policy, 44 (2): 340-356.

Johnson, D.K.N. (2002), Learning by licensing: R\&D and technology licensing in Brazilian invention, Economics of Innovation and New Technology, 11 (3): 163-177.

Kani, M. and Motohashi, K. (2011), Understanding the technology market for patents: New insights from a licensing survey of Japanese firms, Research Policy, 41 (1): 226-235.

Katz, M. and C. Shapiro (1985), Network Externalities, Competition, and Compatibility, The American Economic Review, 75 (3): 424-440

Kim, L. (1997), Imitation to Innovation. The Dynamics of Korea's Technological Learning. Harvard Business School Press, Boston.

Klemperer, P. (1990), How broad should the scope of patent protection be?, Rand Journal of Economics, 21 (1):113.130.

Kogut, B. and U. Zander (1993), Knowledge of the Firm and the Evolutionary-Theory of the Multinational Corporation, Journal of International Business Studies, 24 (4): 625-645

Landes, W. and R. Posner (1987), Trademark Law: An Economic Perspective, Journal of Law and Economics, 30 (2): 265-309

Lanjouw, J. O. and M.A. Schankerman (2001), Enforcing Intellectual Property Rights, NBER Working Paper No. 8656.

Lee, J. (1996), Technology imports and R\&D efforts of Korean manufacturing firms, Journal of Development Economics, 50(1): 197-210

Lerner, J. (1994), The Importance of Patent Scope: An Empirical Analysis, The Rand Journal of Economics, 25 (2): 319-333 
Levin, R., Klevorick, A., Nelson, R., Winter, S., Gilbert, R. and Z. Griliches (1987), Appropriating the Returns from Industrial Research and Development, Brookings Papers on Economic Activity, 3, Special Issue On Microeconomics: 783-831

Macho-Stadler, I., Martinez-Giralt, X. and Pérez-Castrillo, D. (1996), The role of information in licensing contract design, Research Policy, 25 (1), 43-57.

Maddala, G.S. (1983), Limited-Dependent and Qualitative Variables in Economics, New York: Cambridge University Press, 257-91.

Mansfield, E. and A. Romeo (1980), Technology Transfer to Overseas Subsidiaries by U. S.Based Firms, The Quarterly Journal of Economics, 1980, vol. 95, issue 4, pages 737-750

Martinez, C. (2011), Patent families: when do different definitions really matter?, Scientometrics, 86 (1): 39-63

Merges, R. and R. Nelson (1990), On the Complex Economics of Patent Scope, Columbia Law Review, 90, 839 (1990).

Mendi, P. (2007), Contractual implications of international trade in tacit knowledge, Applied Economics, 39 (9): 1173-1183.

Miravete, Eugenio J. \& Pernías, José C., (2010), Testing for complementarity when strategies are dichotomous, Economics Letters, 106(1): 28-31.

Nagaoka, S. and Walsh, J. (2009), Commercialization and other uses of patents in Japan and the US: Major findings from the RIETI-Georgia Tech Inventor Survey. RIETI Discussion paper, February 2009, Tokyo Japan.

OECD (2009), Patent Statistics Manual, OECD, Paris.

Pavitt, K. (1987), On the nature of technology, University of Sussex.

Polanyi, M. (1966), The tacit dimension, University of Chicago Press: Chicago.

Rocha Amorim, R. and C. Gomez de Souza (2011), Technology transfer in Brazil. A study of contracts for the exploitation of patents registered by the Brazilian Patent Office, 20012006, Information Development, 27: 46-57.

Rockett, K. (1990), Choosing the Competition and Patent Licensing, The Rand Journal of Economics, 21(1): 161-171

Rosenberg, N. (1983), Inside the black box: technology and economics, Cambridge University Press, Cambridge, UK.

SCImago. (2012). SJR SCImago Journal and Country Rank. Retrieved April 11, 2012, from http://www.scimagojr.com

Squicciarini, M., Dernis, H. and C. Criscuolo (2013), Measuring Patent Quality: Indicators of Technological and Economic Value, OECD Science, Technology and Industry Working Papers 2013/3, OECD Publishing. 
Taylor, C. and Z. Silberston (1973), The Economic Impact of the Patent System: A Study of the British Experience, Cambridge, UK: Cambridge University

Teece, D. (1986), Profiting from technological innovation: implications for integration, collaboration, licensing and public policy, Research Policy, 15 (6): 285-305.

Torrrisi, S., Gambardella, A., Giuri, P., Harhoff, D., Hoisl, K., and M. Mariani (2016), Used, blocking and sleeping patents: Empirical evidence from a large-scale inventor survey, Research Policy, 45: 1374-1385.

van Zeebroeck, N. (2008), Essays on the empirical analysis of patent systems, ULB Institutional Repository 2013/210551, Universite Libre de Bruxelles.

van Zeebroeck, N. (2011), The puzzle of patent value indicators, Economics of Innovation and New Technology, 20(1): 33-62.

Wagner, S. and S. Wakeman (2016), What do patent-based measures tell us about product commercialization? Evidence from the pharmaceutical industry, Research Policy 45(5): $1091-1102$

Williamson, O. (1991), Comparative Economic Organization: The Analysis of Discrete Structural Alternatives, Administrative Science Quarterly, 36: 269-296.

Zuniga, P. and D. Guellec (2009), Who licenses out patents and why? Lessons from a business survey, STI Working Paper 2009/5, OECD, Paris. 


\section{ANNEX TABLES}

Table A1. Breakdown of international technology contracts with patent licensing by payment types

\begin{tabular}{|c|c|c|c|c|c|c|c|c|}
\hline \multirow[b]{2}{*}{ Upfront } & \multicolumn{2}{|c|}{ All } & \multicolumn{2}{|c|}{ Know-how } & \multicolumn{2}{|c|}{ IPR bundle } & \multicolumn{2}{|c|}{$\begin{array}{c}\text { Know-how } \\
\text { \& IPR bundle } \\
\end{array}$} \\
\hline & 30 & $19 \%$ & 20 & $29 \%$ & 1 & $2 \%$ & $\mathbf{0}$ & $\mathbf{0 \%}$ \\
\hline Royalty & 54 & $34 \%$ & 22 & $32 \%$ & 16 & $38 \%$ & 10 & $53 \%$ \\
\hline Combined payment & 74 & $47 \%$ & 26 & $38 \%$ & 25 & $60 \%$ & 9 & $47 \%$ \\
\hline ---Royalty + min. per year & 22 & $14 \%$ & 6 & $9 \%$ & 17 & $40 \%$ & 5 & $26 \%$ \\
\hline ---Upfront + royalty & 42 & $27 \%$ & 16 & $24 \%$ & 6 & $14 \%$ & 3 & $16 \%$ \\
\hline ---Upfront + royalty + min. per year & 7 & $4 \%$ & 2 & $3 \%$ & 2 & $5 \%$ & 1 & $5 \%$ \\
\hline ---Periodical fixed fee & 3 & $2 \%$ & 2 & $3 \%$ & 0 & $0 \%$ & 0 & $0 \%$ \\
\hline Contracts with payment information & 158 & $100 \%$ & 68 & $100 \%$ & 42 & $100 \%$ & 19 & $100 \%$ \\
\hline Contracts without data on payments* & 63 & & 0 & & 6 & & 0 & \\
\hline Total number of contracts & 221 & & 68 & & 48 & & 19 & \\
\hline
\end{tabular}

Note: Contracts with missing data on payments (payment marked as 'nihil') are those which only include pending patents, for which payment terms are then gradually added as patents get granted. 
Table A2: Broad classification of industrial sector of licensees based on groupings of original classes

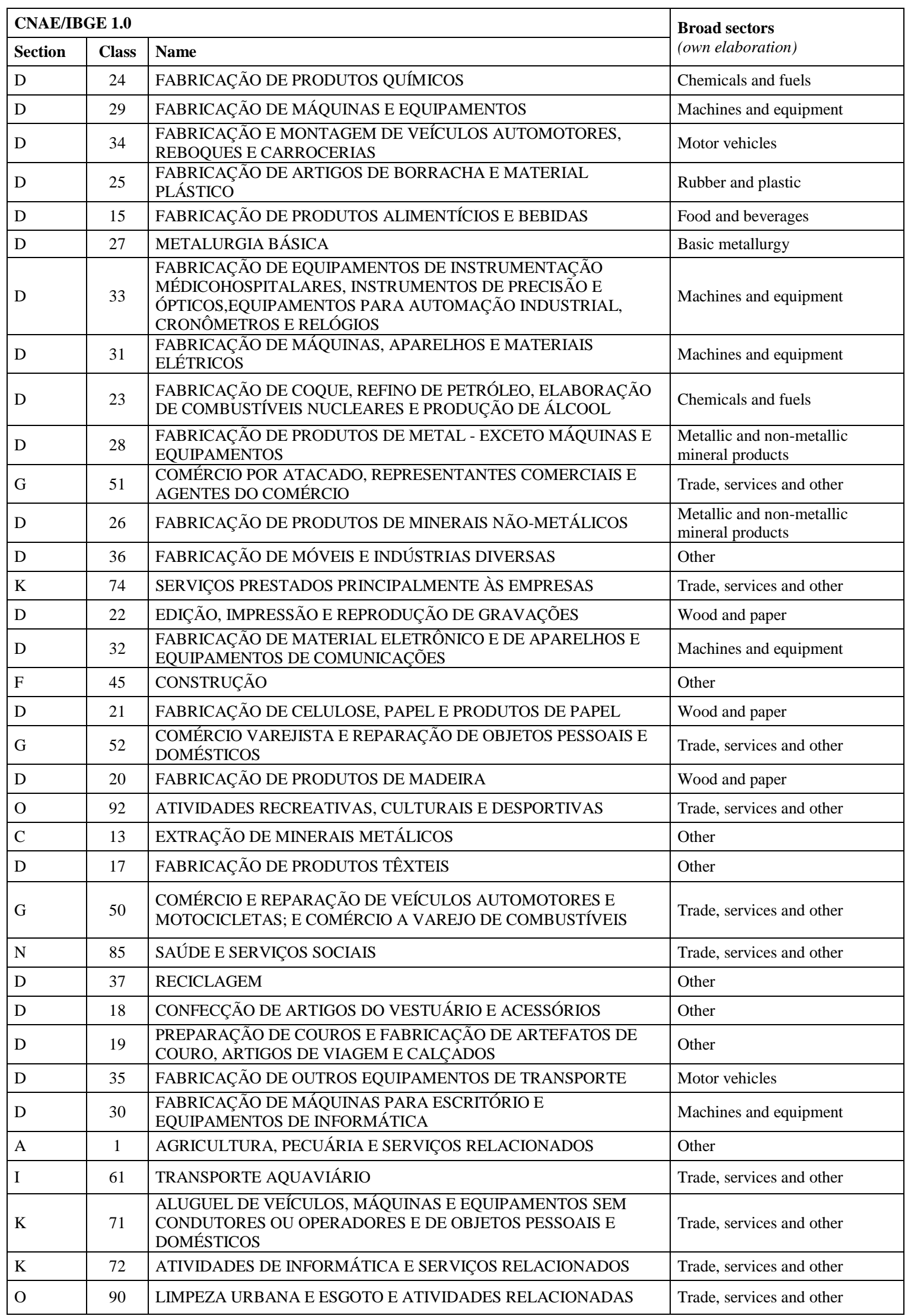

